\title{
Alberta Greater Sage-Grouse Recovery Plan 2005-2010
}
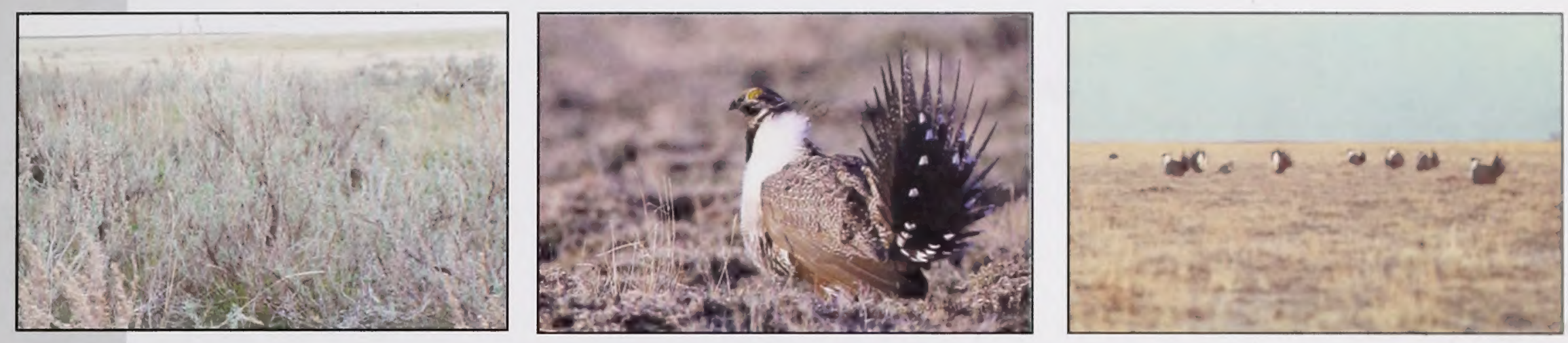

Alberta Species At Risk Recovery Plan No. 8

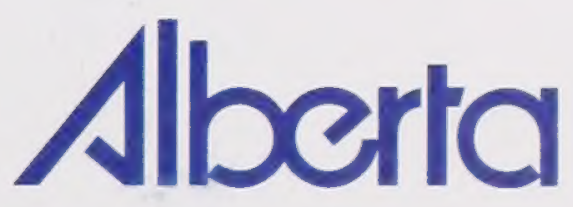


Digitized by the Internet Archive in 2016 


\section{Alberta Greater Sage-Grouse Recovery Plan}

Prepared by:

The Alberta Sage Grouse Recovery Action Group

Dale Eslinger (Chair), Alberta Fish and Wildlife Division

Lee Finstad, Ranching Community

Nicole Haakenson, Canadian Association of Petroleum Producers

Terry Hood (Alternate), Alberta Public Lands and Forests Division

Hank Iwanicki, Medicine Hat Fish and Game Club

Dennis Kusler, Ranching Community

Brad Lloyd, Alberta Energy

Dennis Milner, Alberta Public Lands and Forests Division

Joel Nicholson (Alternate), Alberta Fish and Wildlife Division

Wayne Murray, Ranching Community

Jo-Anne Reynolds, Society of Grasslands Naturalists 
Publication No.: I/231

ISBN: $0-7785-4515-6$

ISBN: $0-7785-4516-4$

ISSN: $1702-4897$

ISSN: $1702-4900$

Cover photos:

Silver sagebrush - Joel Nicholson

Greater sage-grouse - Gordon Court

Sage-grouse lek - William Wishart

For copies of this report, contact:

Information Centre - Publications

Alberta Sustainable Resource Development

Main Floor, Great West Life Building

9920 - 108 Street

Edmonton, Alberta, Canada T5K 2M4

Telephone: (780) 422-2079

\section{OR}

Visit the Alberta Species at Risk Program's web site at:

http://www3.gov.ab.ca/srd/fw/speciesatrisk/

This publication may be cited as:

Alberta Sage Grouse Recovery Action Group. 2005. Alberta Greater Sage-Grouse Recovery Plan. Alberta Sustainable Resource Development, Fish and Wildlife Division, Alberta Species at Risk Recovery Plan No. 8. Edmonton, AB. 33 pp. 


\section{PREFACE}

Albertans are fortunate to share their province with a diverse variety of wild species. Populations of most species of plants and animals are healthy and secure. However, a small number of species are either naturally rare or are now imperilled because of human activities. Recovery plans establish a basis for cooperation among government and stakeholders to ensure these species and populations are restored or maintained for future generations.

Alberta's commitment to the Accord for the Protection of Species at Risk and to the National Framework for the Conservation of Species at Risk, combined with requirements established under Alberta's Wildlife Act and the federal Species at Risk Act, has resulted in the development of a provincial recovery program. The overall goal of the recovery program is to restore species identified as Threatened or Endangered to viable, naturally self-sustaining populations within Alberta.

Alberta species at risk recovery plans are prepared under the supervision of the Fish and Wildlife Division, Alberta Sustainable Resource Development. These recovery plans are prepared by recovery teams composed of a variety of stakeholders including conservation organizations, industry, landowners, resource users, universities, government agencies and others. Membership is by invitation from the Director of Wildlife Management, and includes representation from the diversity of interests unique to each species and circumstance. Conservation and management of these species continues during preparation of the recovery plan.

Recovery plans include three main sections: background information that highlights the species' biology, population trends and threats; a recovery section that outlines goals, objectives, and strategies to address the threats; and an action plan that profiles priority actions required to maintain or restore the Threatened or Endangered species.

These plans are provided by the recovery team as advice to the Minister of Sustainable Resource Development (the Minister; the Department) and to all Albertans. The Department, other provincial departments, as appropriate, and Alberta's Endangered Species Conservation Committee review draft recovery plans, and provide recommendations to the Minister. In addition, an opportunity for review by the public is provided.

Approved plans are a summary of the Department's commitment to work with involved stakeholders to coordinate and implement conservation actions necessary to restore or maintain these species. Recovery plans are "living" documents and are revised as conditions change or circumstances warrant. Implementation of each recovery plan is subject to the availability of resources, from within and from outside government.

The Alberta Greater Sage-Grouse Recovery Plan was reviewed by the Endangered Species Conservation Committee in June 2005. The committee subsequently recommended to the Minister that the plan be approved as written, and implemented. On December 16, 2005, the Minister approved the recovery plan and directed the Department to continue the cooperative approach taken in recovery planning to enhance the implementation of the recovery program for sage-grouse in Alberta. 


\section{TABLE OF CONTENTS}

PREFACE iii

LIST OF FIGURES $\mathrm{V}$

ACKNOWLEDGEMENTS ___ vi

EXECUTIVE SUMMARY __ vii

1.0 INTRODUCTION

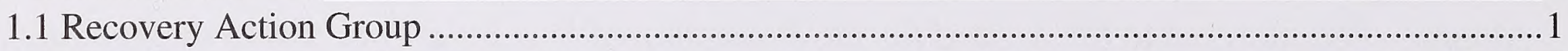

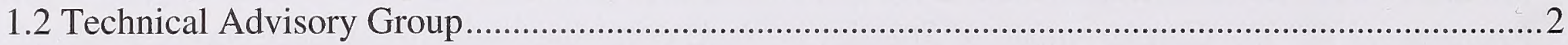

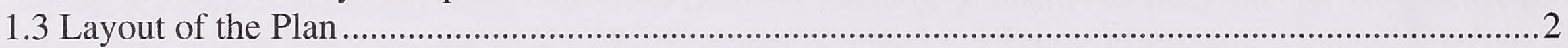

2.0 SAGE-GROUSE BIOLOGY__ 2

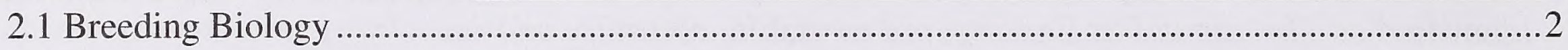

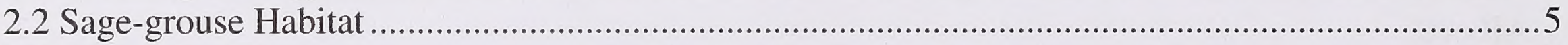

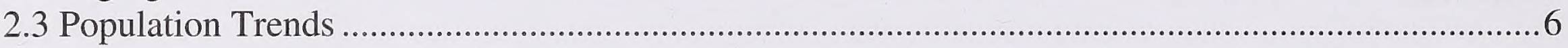

3.0 THREATS _ 7

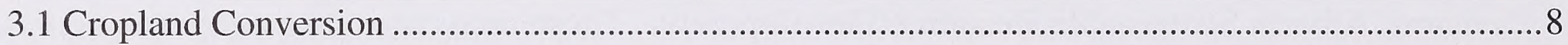

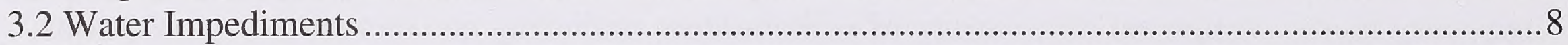

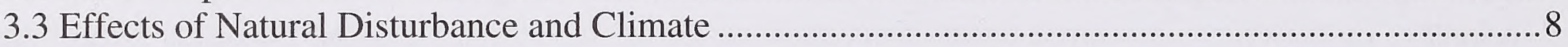

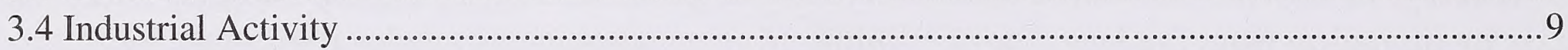

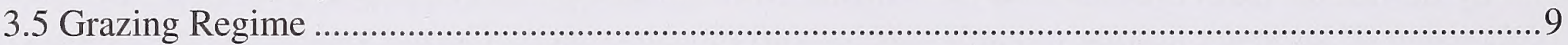

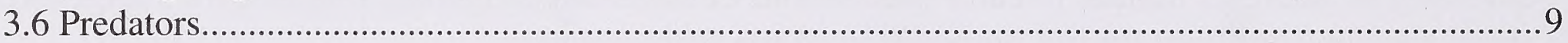

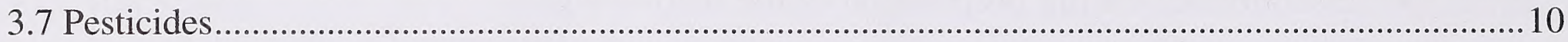

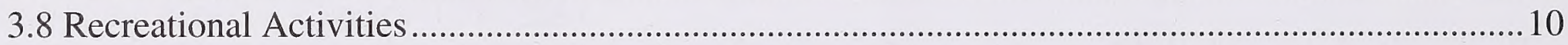

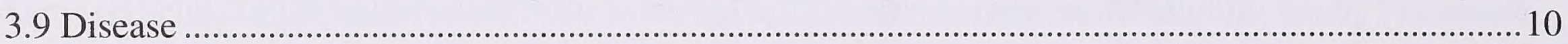

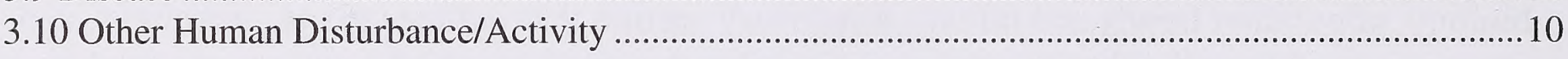

4.0 ESSENTIAL HABITAT _ 10

5.0 INFORMATION GAPS AND RESEARCH PRIORITIES _ 12

6.0 BIOLOGICAL AND TECHNICAL FEASIBILITY OF RECOVERY _ 13

7.0 RECOVERY STRATEGY _ 14

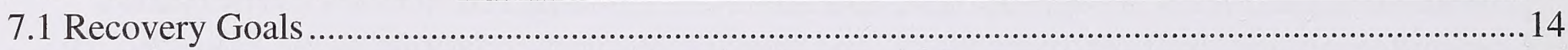

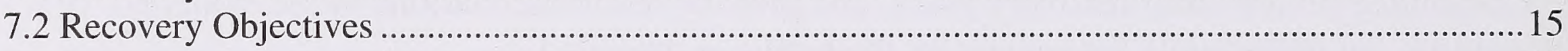

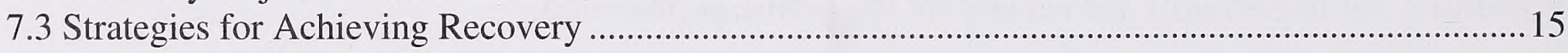

8.0 ACTION PLAN _ 17

9.0 TIMETABLE FOR IMPLEMENTATION AND SCHEDULE OF COSTS __ 24

10.0 ECONOMIC IMPLICATIONS OF RECOVERY ACTIONS _ 28

10.1 Activities Related to Ranching ...................................................................................28

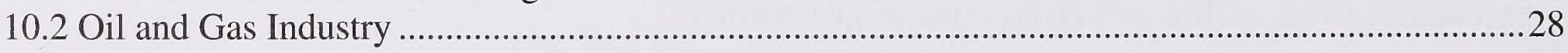

11.0 PLAN MANAGEMENT, REVIEW AND AMENDMENT _ 29

12.0 REFERENCES _ 30 


\section{LIST OF FIGURES}

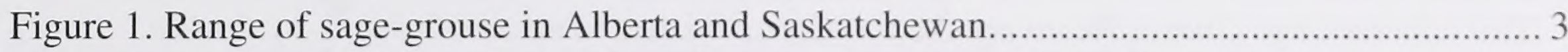

Figure 2. Sage-grouse life cycle timeline.

Figure 3. Fish and Wildlife Division annual sage-grouse lek survey 1968-2004_....................... 7

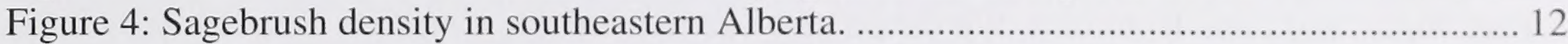

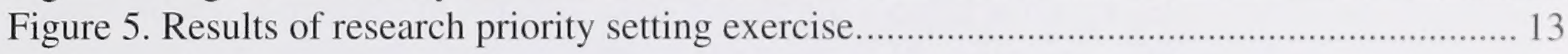




\section{ACKNOWLEDGEMENTS}

The Alberta Sage Grouse Recovery Action Group wishes to acknowledge the valuable contributions of the sage-grouse Technical Advisory Group established to support this team. Members include Barry Adams, Ron McNeil, Roy Penniket, Cam Aldridge, Dr. Mark Boyce, Paul Jones, and Lana Robinson. We would also like to thank Dr. Cormack Gates for providing direction to the process as an academic advisor.

Sue Cotterill is acknowledged for editing and critically reviewing the drafts of this recovery plan.

Jennifer Chandler, graduate student, University of Calgary, provided invaluable support as secretariat and in plan preparation.

Oriano Castelli developed mapping products for the plan.

The team also wished to thank Dennis Ulrich, Gerald Maser and Hyland Armstrong for additional input into the plan.

The Species at Risk Program of Alberta Sustainable Resource Development funded the preparation of the recovery plan. 


\section{EXECUTIVE SUMMARY}

Greater sage-grouse (Centrocercus urophasianus), the largest grouse in North America, is a year-round resident of the sagebrush range of the semi-arid mixed-grass prairie regions of southeastern Alberta, southwestern Saskatchewan, and parts of eleven western states in the United States. Currently in Alberta, sage-grouse are located in the extreme southeastern corner of the province, centered south and east of the town of Manyberries. This $4000 \mathrm{~km}^{2}$ area contains extensive native prairie and sagebrush flats which form unique habitat for sage-grouse. Canadian sage-grouse are entirely dependent on silver sage as a source of food and shelter. Sagegrouse have experienced decline in all parts of their range, and in Canada have been considered Endangered since 1998. The Minister of Sustainable Resource Development approved sagegrouse for listing as Endangered in Alberta in 2000.

The Canadian Sage Grouse Recovery Team was formed in 1997 to address the population decline and recommend strategies for recovery in the Canadian Sage Grouse Recovery Strategy. In late 2002, the Minister of Sustainable Resource Development formally delegated the responsibility of drafting a provincial recovery plan to the Sage Grouse Recovery Action Group. This recovery plan serves as a follow up to the Canadian Strategy, with the purpose of recommending actions in the spirit of enabling sage-grouse recovery in a manner that respects livelihoods and current land uses within sage-grouse range.

The source of the species decline is poorly understood. However, many potential threats have been identified, including cropland conversion south of the Alberta border that effectively isolates the Alberta population. Water impediments may affect the health of the silver sagebrush communities required for sage-grouse survival. Increasing industrial activity is known to cause disturbance to the birds and contributes to fragmentation of habitat. Light to moderate grazing regimes currently in place favour sage-grouse, but recurring drought and climate change may have an impact. Predation and human disturbance from recreational activity also play a role.

The Sage Grouse Recovery Action Group believes sage-grouse can recover based on the following:

- there is remaining habitat to support sage-grouse.

- there is adequate technical information to define management actions that will benefit recovery.

- there is interest in the local community to participate in sage-grouse recovery efforts.

To that end, the Sage Grouse Recovery Action Group defined two goals to promote sage-grouse recovery. These goals are to:

1. Enhance and maintain habitat for sage-grouse to satisfy life cycle requirements in support of a viable population within its remaining historical range.

2. Achieve recovery of the sage-grouse population to a level that provides for sustainable recreational viewing and hunting. 
The recovery plan will serve a period of five years (2005-2010), but will be updated annually, or as needed, with relevant information from modeling exercises and research activities currently being conducted. A series of actions for each goal with measurable objectives, timelines and responsible parties are detailed. A major part of the effort is to promote coordination of oil and gas activity thereby reducing impact on habitat. Reclamation of roads and well sites no longer in production should serve in reducing the impacts of the industrial footprint. Promoting good range health in an effort to maintain existing habitat on rangelands will also help. Translocation of birds from other jurisdictions to augment the Alberta population is also under strong consideration.

The cost of implementing the recovery plan is estimated at $\$ 1,215,000.00$ over five years, including cash and in-kind support. A variety of agencies will be invited to participate in the funding and implementation of recovery actions. In considering recovery actions, an attempt was made to draw on existing programs, such as range health scores that are already being collected in the region, to reduce costs and effort associated with implementation. 


\subsection{INTRODUCTION}

Greater sage-grouse was listed as Threatened by the Committee on the Status of Endangered Wildlife in Canada (COSEWIC see http://www.cosewic.gc.ca/eng/sct5/index_e.cfm) in 1997. and this listing was upgraded to Endangered in 1998. This status was reconfirmed in 2000) (COSEWIC 2004), and the species is now listed as Endangered under the federal Species at Risk Act. In Alberta, greater sage-grouse was added to the general status 'blue list' of may be at risk species in 1996 (Alberta Wildlife Management Division 1996). A formal provincial status assessment was completed in 1999 and the greater sage-grouse was subsequently listed as Endangered under Alberta's Wildlife Act in 2000.

The Canadian Sage Grouse Recovery Team was formed in 1997 to address the population decline and recommend strategies for recovery. This resulted in the Canadian Sage Grouse Recovery Strategy (the Canadian Strategy), being completed in 2001 (Canadian Sage Grouse Recovery Team 2001). The following background material in this provincial recovery plan has been mostly taken verbatim from the Canadian Strategy, with some additional summarization of details added.

The Canadian Strategy considered the recovery potential of sage-grouse and broad areas where action could be taken for recovery. The Alberta Greater Sage-Grouse Recovery Plan serves as a follow up to the Canadian Strategy. The purpose of the provincial plan is to further progress toward the goal set out in the Strategy, which was to "recommend measures which will enable the sage-grouse population in Alberta and Saskatchewan to recover to self-sustaining levels so that the species is not threatened or endangered" (Canadian Sage Grouse Recovery Team 2001). The actions prescribed in this recovery plan were developed in the spirit of enabling sage-grouse recovery in a manner that respects livelihoods and current land uses within sage-grouse range.

\section{$\underline{1.1 \text { Recovery Action Group }}$}

Under Alberta's Wildlife Act, the Minister of Sustainable Resource Development is responsible for preparing recovery plans. This responsibility has been formally delegated to the Sage Grouse Recovery Action Group (SGRAG). The SGRAG includes representatives who may be affected by the management of sage-grouse and its habitat, including:

- Alberta Energy

- Alberta Fish and Game Association

- Alberta Sustainable Resource Development, Fish and Wildlife Division

- Alberta Sustainable Resource Development, Public Lands and Forests Division

- Canadian Association of Petroleum Producers

- Local Ranching Community

- Society of Grasslands Naturalists

All decisions made in writing this recovery plan, including agreement on the actions stated in this document, were achieved by consensus of the SGRAG. The SGRAG was able to voice concerns and provide localized information to help develop a set of recovery actions. To that extent, this plan represents a package of agreements developed by local representatives. 


\subsection{Technical Advisory Group}

A Technical Advisory Group reporting to the SGRAG provided the scientific information needs regarding the effects of grazing, water impediments, sage-grouse ecology and silver sage ecology. While not directly involved in decision-making, this team provided valuable advice on request from the SGRAG and contributed a great deal to discussion of appropriate goals, objectives, indicators and actions. This group consisted of wildlife mangers, researchers, range management specialists, and GIS experts. The Technical Advisory Group's expertise was used to complement local knowledge of the SGRAG to develop a set of actions that will facilitate sagegrouse recovery.

\subsection{Layout of the Plan}

This plan outlines the biology of the species, a description of sage-grouse habitat, and threats to the recovery of the species. Recovery goals, objectives, and strategies to deal with threats are outlined. The action plan focuses on action items, indicators and associated timelines. Where possible, agencies that will be responsible for action items are noted. The plan concludes with an economic analysis of the action items for the ranching and oil and gas industries and a timeline for plan review.

\subsection{SAGE-GROUSE BIOLOGY}

\subsection{Breeding Biology}

(Excerpts have been taken from, and a full list of citations are available, in the Canadian Sage Grouse Recovery Strategy, Canadian Sage Grouse Recovery Team 2001)

Greater sage-grouse, the largest grouse in North America, is a year-round resident of the sagebrush range of the semi-arid mixed-grass prairie regions of south-eastern Alberta. Sagegrouse are totally dependent on sagebrush as a source of food and shelter (Patterson 1952, Schroeder et al. 1999). Sage-grouse food consists primarily of sagebrush leaves, supplemented at various life stages by forbs and insects within the sagebrush-grassland community.

Due to the species' obligate association with sagebrush, the distribution of sage-grouse often follows the distribution of sagebrush. Historical records and anecdotal information indicates that the sage-grouse once occurred in suitable habitat as far northeast as Elkwater (Armstrong 1968) and the Walsh Flats (Mitchell 1959, Banasch 1985), and extending north of Medicine Hat along the South Saskatchewan River as far as Empress. This range extended to the west just north of Brooks (Sadler and Myers 1976), and south to Champion, likely including the Lethbridge area (Figure 1). This historical range encompassed an area of approximately $49000 \mathrm{~km}^{2}$ in Alberta (Aldridge 1998). Currently, sage-grouse are isolated to the extreme southeastern corner of the province, centered south and east of the town of Manyberries. This $4000 \mathrm{~km}^{2}$ area contains extensive native prairie and sagebrush flats which forms unique habitat for sage-grouse (Aldridge 1998). 


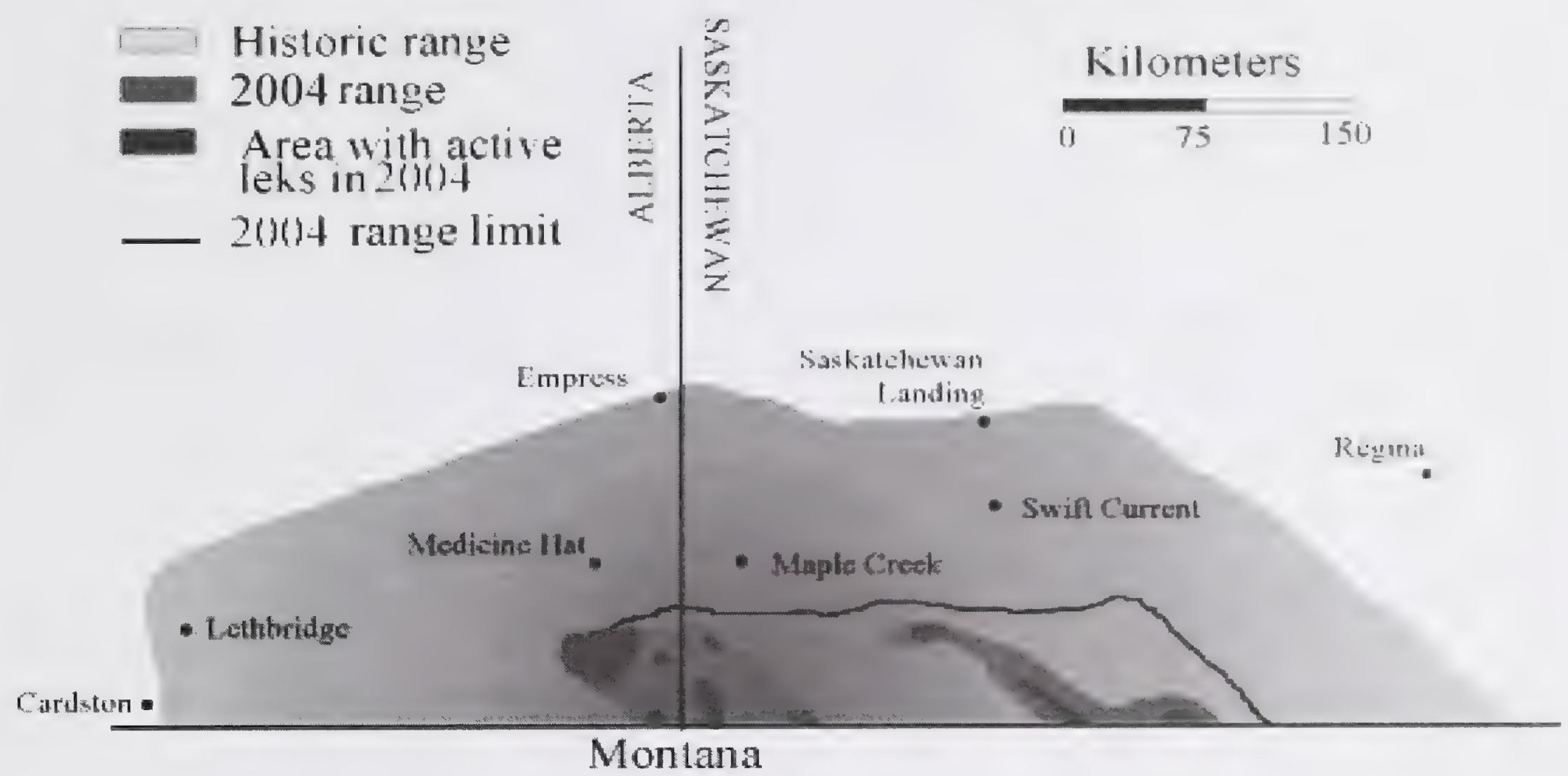

Figure 1. Range of sage-grouse in Alberta and Saskatchewan.

Male sage-grouse gather on "strutting grounds" or "leks" each spring (beginning in early March) and perform a strutting display to attract and mate with females (see Figure 2). Males display at dawn and dusk, with peak activity at sunrise (Braun 1998). Older, dominant males typically are the first to arrive on the lek and establish territories near the center (Aldridge and Brigham 2002). Yearling males arrive later and are found around the edges. Yearling males rarely breed, while central, older males have a greater chance of mating. Leks with higher numbers of males generally have greater female grouse attendance (Aldridge and Brigham 2002). Numbers of males on the leks peaks during April, tapering out entirely by the end of May. Adult males typically use the same leks repeatedly if females attend these leks consistently each year (Braun 1998).

In Alberta, female sage-grouse (hens) typically arrive on the lek in April, and are usually only present at the lek for two to three days. Hens move among displaying males either individually or in groups and usually copulate only once unless the first nesting attempt fails during incubation (Braun 1998). Hens will return to the same lek in subsequent years if nesting habitat around the lek remains stable (Hartzler and Jenni 1998). Females favour leks with suitable nesting habitat nearby. In Alberta, a recent study found that sage-grouse nests were an average of $4.7 \mathrm{~km}$ from leks (Aldridge 2000a). In other parts of their range, nests were an average of 3.2 $\mathrm{km}$ from leks (Sveum et al. 1998). Individual birds in Alberta have been documented traveling very long distances (e.g. $15.5 \mathrm{~km}$ ) to establish nests (Aldridge and Brigham 2002). 
It takes 11 days on average for females to lay all of their eggs, based on an average clutch size of between 7 and 9 eggs for first nests, and 1.3 days between laying successive eggs (Watters et al. 2002). In Alberta, eggs are incubated for an average of 27 days (Canadian Sage Grouse Recovery Team 2001). Incubation typically starts approximately 3 weeks after copulation (Braun 1998). In Alberta, females begin nest searching in early April, prior to attending leks, and begin laying eggs by mid-April (Watters et al. 2002). Variations in weather have caused fluctuations of up to 1-2 weeks in the date of nest initiation (start of egg laying) (Schroeder et al. 1999, Aldridge 2000a). If the nest is not lost to predation or other factors during incubation, peak hatching occurs in late May or early June (Watters et al. 2002). If the first nest fails and the hen renests, the second nest hatch date for grouse in Alberta is on average in the last week of June (Watters et al. 2002). The primary cause of nest failure is predation. Richardson's ground squirrels, American crows, and black-billed magpies are among the most common sage-grouse nest predators in Alberta (Connelly et al. 2000). Other common grouse predators include raptors, raccoons, coyotes and foxes (Connelly et al. 2000).

Grouse chicks are "precocial" (i.e. born with down feathers, eyes open and able to move about). Chicks begin to fly by about 10 days of age (Braun 1998). Immediately after hatching, broods (all chicks) move off the nest to areas with succulent herbaceous plants and with good cover. The brood rearing period lasts from the time of hatch until chicks are about 12 weeks of age (Watters et al. 2002).

Sage-grouse begin gathering in flocks in late summer and fall. Male and female grouse flock separately, but young males may flock with hens. Where sagebrush cover is suitable, grouse may remain in the same general area year-round. To cope with severe winter conditions, sage-grouse may excavate burrows in the snow deep enough to cover themselves completely.

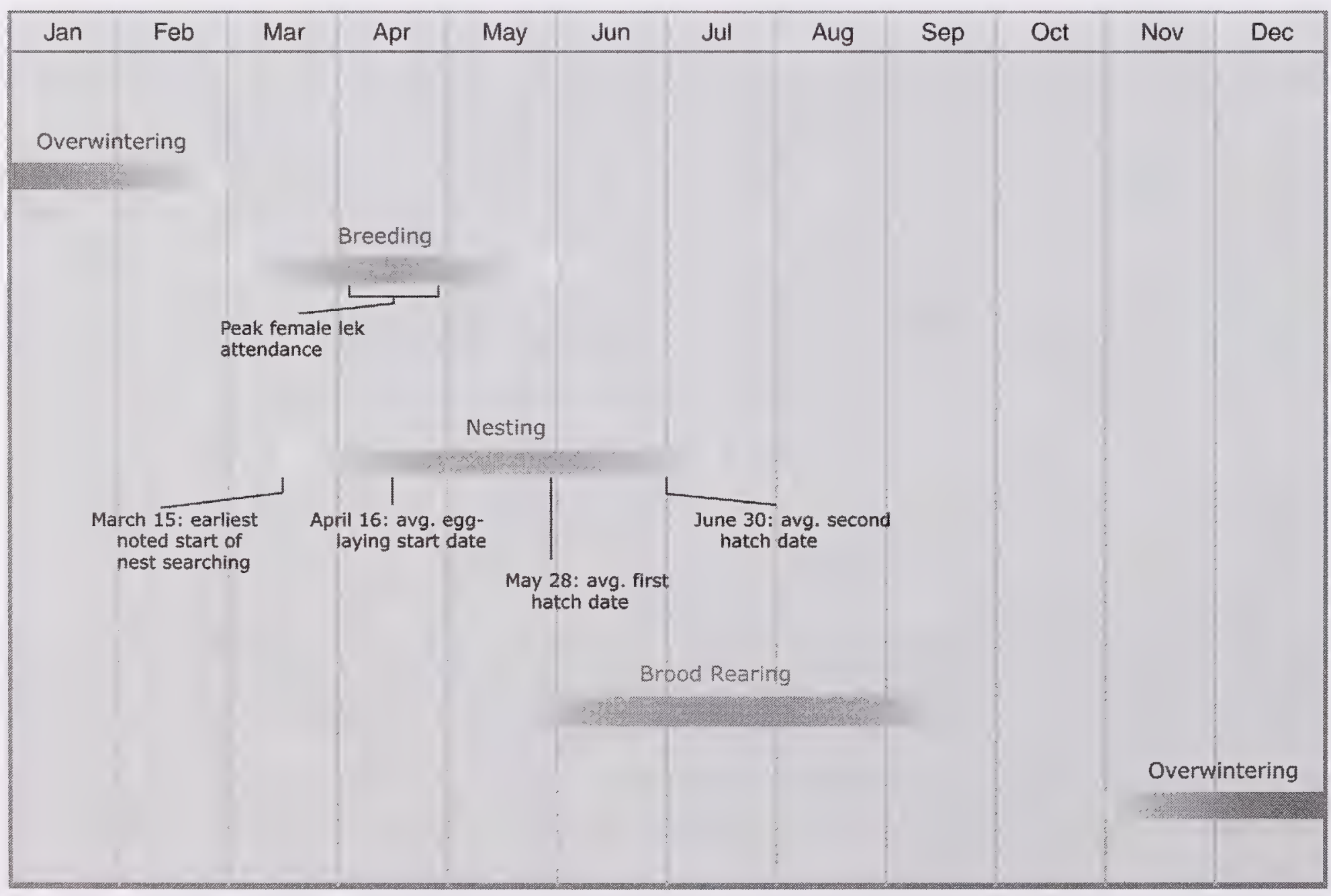

Figure 2. Alberta sage-grouse life cycle timeline. 


\subsection{Sage-grouse Habitat}

Sage-grouse are dependent on sagebrush for survival during all seasons of the year (Hagen 1999). Studies conducted in the United States indicate that sage-grouse require a variety of sagebrush habitats during various stages of their life cycle. Mating areas on leks generally have very sparse vegetation ( $<26 \%$ ground cover) with sparse $(7 \%$ cover) and short sagebrush $(<10$ $\mathrm{cm}$ ) (Peterson 1980). Areas near leks which are used by adults for daytime loafing and feeding consist of taller $(15-30 \mathrm{~cm})$ sagebrush (Peterson 1980). Nests are almost always under tall sagebrush plants $(27-76 \mathrm{~cm})$ (Peterson 1980).

In the dry mixed-grass ecoregion of southeastern Alberta, sage-grouse habitat is limited to the distribution of silver sagebrush (Artemisia cana), which, in prairie Canada, is generally most abundant in riparian corridors. Silver sagebrush is the principal food source for adult grouse during the summer and probably throughout the year. It also provides necessary escape and thermal cover in grasslands, much of which offer relatively little topographical relief for shelter or concealment. During the summer, sage-grouse broods consume a greater variety of legumes and forbs, and more insects than adults do.

The extent of seasonal movements among habitats is not well documented in Alberta and Saskatchewan although recent work by Aldridge (2000a) does provide some insight into habitat use by sage-grouse in Alberta. Analysis of recent and ongoing research in Alberta will continue to refine understanding of habitat use by sage-grouse in southeastern Alberta. Adams et al. (2004) also investigated the ecology of silver sagebrush and the relationships of sagebrush plant communities to the sage-grouse life cycle. General seasonal habitat requirements for sage-grouse are summarized as follows:

\subsubsection{Breeding}

Open relatively level areas of short or sparse vegetation near sagebrush flats are required for leks, where displaying males are readily visible to females and to each other. These typically range from 0.04 ha to greater than 1.0 ha in size and are in native grasslands near watercourses (Dalke et al. 1963, Weichel and Hjertaas 1992). Sagebrush density within a radius of $3.2 \mathrm{~km}$ of 25 known leks in Alberta ranged from light (3-10 plants per $61 \mathrm{~m}$ transect) to heavy ( $>25$ plants per $61 \mathrm{~m}$ transect) (Clark and Dube 1984).

\subsubsection{Nesting}

In Alberta, Aldridge (2000a) found an average lek-to-nest distance of $4.7 \mathrm{~km}$, ranging from 0.42 to $15.45 \mathrm{~km}$. Nest concealment requires both vertical and horizontal cover from sagebrush of different heights with good inter-sagebrush growth of grasses and forbs (Weichel and Hjertaas 1992, Madsen 1995, Patterson 1952, Wallestad and Pyrah 1974, Klebenow 1969). Aldridge (2000a) found that nearly $90 \%$ of sage-grouse nests were located under silver sagebrush and understory grass cover that was taller than average. In Alberta, one study found that successful nests are generally located under tall, silver sagebrush with an average height of about $40 \mathrm{~cm}$, and an average of $32 \%$ canopy cover over the nest (Braun et al. 1977). 
Successful nests are also associated with tall $(>18 \mathrm{~cm})$, dense $(31 \%$ cover) residual grass cover at nest sites (DeLlong and Crawford 1993, Gregg et al. 1994). Broods use areas that have lower shrub density (<31\% cover) where forbs and insects are more prevalent. Hens with broods do not use denser stands, probably because fewer forbs are present. Adult hens with broods move to moist areas which support succulent vegetation (Wallestad 1975).

\subsubsection{Brood Rearing}

In Saskatchewan, hens with broods were found to make limited movements, up to a few hundred metres, from nest sites (Weichel and Hjertaas 1992). Hens with broods concentrate in more open and moist sagebrush grasslands where succulent forbs and a greater variety of insects are plentiful (Banasch 1985, Drut et al. 1994, Klebenow 1969, Patterson 1952, Wallestad 1971). Proximity to water is likely of greater importance in drought years as meadows with available surface water have been shown to be preferred by sage-grouse (Oakleaf 1971). Hens and broods may move further from sagebrush flats into wet meadow areas in search of forbs near open water during late summer (Drut et al. 1994, Klebenow 1969, Patterson 1952, Wallestad 1971). In Alberta, Aldridge (2000a) did not find any noticeable shift of sage-grouse into mesic habitat and concluded that the lack of moist areas for foraging by broods may contribute to low chick survival and poor recruitment.

\subsubsection{Overwintering}

In some winters, snow cover may limit accessibility to sagebrush stands, restricting use to tall stands or those on slopes with exposures to southwest winds. Sagebrush stands along drainages in Alberta are thought to be important for both winter and summer range (Vriend and Gudmundson 1995). During winter, sage-grouse distribution is influenced by topography, variation in snow depth and exposure of sagebrush above snow (Hupp and Braun 1989). Structurally, winter sage-grouse habitat is similar to the areas around leks which are used for loafing and feeding (20-30\% canopy cover) (Wallestad and Schladweiler 1974, Wallestad 1975). During periods of deep snow cover, birds will move into areas that contain the tallest sagebrush plants. They tend to seek out wintering areas which will have south or southwest facing slopes where more sagebrush may be exposed above the snow (Hupp and Braun 1989). Work underway in Alberta that is assessing winter habitat use by sage-grouse may help refine understanding of sage-grouse wintering habitat characteristics in the province.

\subsection{Population Trends}

Sage-grouse populations in Canada have declined by at least $80 \%$ from historical levels (Aldridge 1998) and no recovery has been documented in recent years. The simplest way to obtain population estimates for sage-grouse is through the use of lek counts. Lek counts are simply the enumeration of all male sage-grouse displaying on a dancing ground during the mating season. The maximum number of males observed on each lek is then used as an index of population status and to estimate overall population size (Beck and Braun 1980).

In Alberta, lek counts have been performed on an irregular basis since 1968. In the late 1960s, counts in Alberta showed an annual average of about 600 males. The number of males observed 
dropped significantly during the 1970 s, rose to a peak of 524 males in 1981, fluctuated during much of the 1980s, followed by sustained low numbers from 1994 onward. However, for many of these annual counts, not all known leks were surveyed and, in some years, it is unclear which leks were surveyed (Aldridge 1998). Over the last 10 years, concerted spring survey efforts recorded from 70 to 136 males in Alberta (Figure 3).

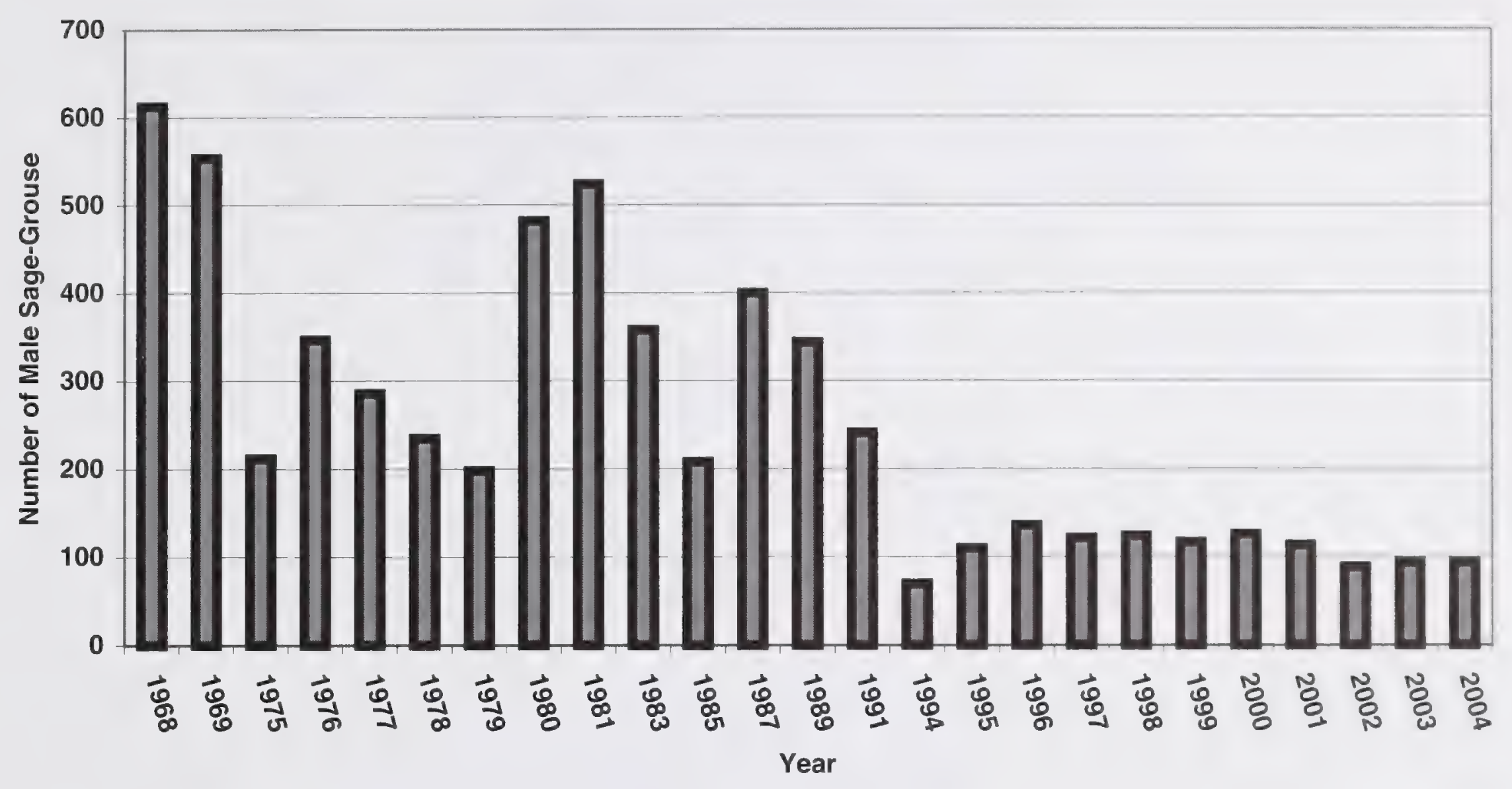

Figure 3. Fish and Wildlife Division annual sage-grouse lek survey 1968-2004.

\subsection{THREATS}

(Excerpts taken from, and a full list of citations in, the Canadian Sage Grouse Recovery Strategy, Canadian Sage Grouse Recovery Team 2001)

The exact causes for the decline in sage-grouse numbers are not known. Survival of sage-grouse on the remaining range is complicated by a number of factors that are shared by other species at risk within the prairie ecosystem. Fundamentally the entire remaining native prairie habitat is allocated to agricultural use, principally widespread livestock grazing. Oil and gas exploration results in establishment of well sites, pipelines, pumping stations, power lines and access roads throughout the range. Wildlife viewing enthusiasts frequented some of the more obvious leks for opportunities to view and photograph displaying males. The effects of climate change and potential future climate change are not well understood. Predator complexes have changed substantially from historical periods.. Widespread cultivation in northern Montana may have isolated the once connected Alberta population. The combination of factors which may potentially impact sage-grouse and the complex interrelationships between these factors are likely cumulative. 
Historical hunting of sage-grouse in Alberta does not seem to be a causal factor in the decline of the species. Harvest was directed only at male birds, and was very restrictive. Additionally, the population in Saskatchewan, which was not hunted, exhibited the same simultaneous rapid decline as in Alberta. Sage-grouse have not been hunted in Alberta since 1995.

There are factors known to limit reproduction and survival of sage-grouse. These factors can be broadly categorized into habitat loss and degradation, human disturbance and other variables such as weather, disease and predation. Specific threats to sage-grouse population and habitat include:

\subsection{Cropland Conversion}

Eustace (1995) identified the conversion of sage-grouse habitat in the United States as a major contributor in the decline in distribution and abundance of the species. In Alberta, this is not presently a major factor as little sage-grouse habitat is being converted. However, a large swath of cultivation directly south of the Alberta-Montana border has effectively isolated the Alberta population from those in Montana. Research being conducted at the University of Alberta on the genetics of the Alberta population will provide insight into the extent of population isolation.

\section{$\underline{3.2 \text { Water Impediments }}$}

Periodic flood events are required to sustain the health of silver sagebrush habitats. Impediments that capture runoff, such as dams, dugouts, berms and reservoirs, reduce the amount of available runoff and sedimentation, which compromises the health of silver sagebrush habitats. Within the Alberta range of sage-grouse the area affected by surface water impediments has increased almost four-fold between 1951 and 2001, from 535 impediments to 1890 . The potentially affected area upslope of impediments has also dramatically increased, from $24.4 \%$ of the range in 1951, to $80.7 \%$ in 2001 (McNeil and Sawyer 2003). That is, less than $20 \%$ of the current study area does not drain to impediments today.

The percentage of runoff captured by all the impediments in the study area is estimated to range from $25 \%$ to $36 \%$. This estimate is based on a $70 \mathrm{~mm}$ rainfall event with $30 \%$ of the moisture available for runoff (McNeil and Sawyer 2003). However, the estimated amount of captured runoff varies greatly ( 0 to $100 \%$ ) among micro-watersheds, depending on the number and size of impediments in the area. Therefore, impediments in the study area have probably degraded sagebrush habitat at some locations, through reduced overflow to those sites.

\subsection{Effects of Natural Disturbance and Climate}

Recent observations in Alberta (C. Aldridge pers. comm.) have shown sage-grouse to be highly susceptible to natural disturbances such as weather events and climatic cycles. Spring snowstorms caused nest failure and abandonment. Hailstorms resulted in direct mortality of grouse. Floods associated with severe rainstorms also caused nest failure and abandonment. Longer-term drought conditions resulted in a drastic reduction in nest success and deterioration of habitat conditions for sage-grouse. 


\subsection{Industrial Activity}

The levels of industrial activity are increasing across Alberta, including the southeastern portion of the province. Traffic, roads, pipelines, power lines and other human disturbances from oil and gas developments decrease the chance for sage-grouse recovery (Harris 1996). Sage-grouse avoid areas within $0.8 \mathrm{~km}$ of power lines as they are used as hunting perches by raptors (Gilmer and Wiehe 1977, Knight and Kawashima 1993, Steenhof et al. 1993, Anonymous 1996). Increasing numbers of power lines may effectively fragment current habitat. Additionally, direct collisions with power lines are a known cause of mortality in Alberta. Petroleum development contributes to fragmentation of sage-grouse habitat in Alberta (Dube 1993) and increases the potential for mortality and disturbance to the grouse. Recent interest in wind energy in southeastern Alberta also has the potential to increase the industrial footprint in sage-grouse range.

\subsection{Grazing Regime}

The current grazing regime practiced in sage-grouse range tends to promote late-seral plant communities with residual cover and favorable litter reserves for maintenance of range health. Grazing prescriptions that create a degree of patchiness in ground cover are likely desirable for sage-grouse. This tends to mimic the historical grazing regime that resulted in light, moderate and heavy grazing intensity and resulting habitat diversity on the landscape. The current ranching communities, along with their unique skills in rangeland management, are important to the longterm maintenance of rangeland health. The continuity of good stewardship practices is linked to the sustainability of the ranching economy. Overgrazing is considered detrimental for sagegrouse habitat, and also undermines the long-term sustainability of livestock grazing on mixedgrass prairie. Other related threats include recurring drought and climate change, which might result in long-term reductions in sustainable stocking rates.

\section{$\underline{3.6 \text { Predators }}$}

Predators may affect sage-grouse populations differently depending on the size of the predator and the distribution and abundance of other prey populations. Some mammalian species, which form a prey base for coyotes and other predators (ground squirrels, voles, mice and hares), are considered to have decreased since the 1980s (Houston 1999, Harris and McAdam 2000). In her investigation of small mammal abundance as a prey base for swift fox, Klausz (1997) indicates that small mammal trapping results were indicative of low population levels of all small mammal species. She concluded that density and species diversity of small mammals were low in the Canadian Prairies during the 1995-1996 winter. Predators such as coyotes, red foxes, raptors and others may be hunting sage-grouse opportunistically in Canada. In Alberta there is an indication that coyote numbers may have increased substantially from the 1970s to the 1990s (Gudmundson 1996). Skunks, weasels, raccoons, badgers, red foxes, and ground squirrels are also nest predators and some could prey on sage-grouse chicks as well. 


\section{$\underline{3.7 \text { Pesticides }}$}

The use of pesticides in general does not appear to be a significant factor because these products are not used to a great extent in the Canadian range of the sage-grouse. However, some sagegrouse, especially hens with broods, do utilize cultivated cropland during part of their life cycle (C. Aldridge pers. comm.). Studies in the United States have identified mortality and injury of birds resulting from insecticide poisoning. In particular, organophosphates which are contact and systemic insecticides are highly toxic to birds (Ali 1996).

\section{$\underline{3.8 \text { Recreational Activities }}$}

Birdwatching/photography is one of the fastest growing outdoor recreational activities related to wildlife. There is considerable interest in viewing sage-grouse during the spring when males are actively displaying at leks. While increased societal interest in wildlife is considered a positive trend, the tendency for sage-grouse viewers to approach too close to active leks can disrupt breeding activity. Repeated disturbance of birds at lek sites will interfere with mating and can result in abandonment of lek sites.

\subsection{Disease}

In 2003, West Nile virus (WNv) spread into sage-grouse. Mortality of birds was documented in Alberta, Montana, and Wyoming. While the effects of this disease on the population are currently unknown, late summer survival in four affected populations in Alberta, Montana, and northern and southern Wyoming, declined by approximately $25 \%$ when compared to both preWNv infection survival rates and an uninfected control population in 2003 (Naugle et al., 2004).

\subsection{Other Human Disturbance/Activity}

Birds which nest or feed in hay fields may also be killed by haying equipment (Aldridge 2000a). Birds have also been road killed on occasion (Officer L. Lupyczuk, Fish and Wildlife Division, Medicine Hat, pers. comm.). Invasion of exotic plants can compete with native plant species and possibly negatively affect sage-grouse habitat. Invasive exotic plants are often associated with human activities such as road construction, industrial development, livestock feeding, and cultivation.

\subsection{ESSENTIAL HABITAT}

Currently essential habitat for sage-grouse has not been accurately delineated in Alberta. However, due to sage-grouse's obligate relationship with silver sagebrush, the Sage Grouse Recovery Action Group proposes that the recently completed silver sagebrush vegetation mapping project (Jones et al. in press) be utilized as one tool to define essential habitat (see Figure 4). Additionally, Cameron Aldridge has recently completed a PhD. program at the University of Alberta. Sage-grouse habitat models developed using telemetry data collected during Aldridge's study should also contribute to a better understanding of essential habitat. A spatial modeling project co-ordinated by the Miistakis Institute at the University of Calgary is currently underway. The model is based upon the ALCES® software (Forem Technologies 
Ltd.). ALCES ${ }^{\circledR}$ is a landscape simulator that enables resource managers, society, and the scientific community to explore and quantify dynamic landscapes subjected to single or multiple human land use practices and various natural disturbance regimes. The model will be used to provide a decision support tool allowing the Recovery Action Group to determine priority areas for focusing recovery efforts. The model should provide direction through integrating data layers such as sagebrush mapping, sage-grouse telemetry data, habitat models, petroleum industry development data, native prairie vegetation inventory, and information from soils. roads and water impediment studies. A better understanding of essential habitat should result and the model will provide a useful mechanism for understanding how sage-grouse are using the landscape in relation to various components of the anthropogenic landscape footprint.

Perhaps the most imminent change to potential essential habitat predicted by the Sage Grouse Recovery Action Group is the development of oil and natural gas reserves within sage-grouse habitat. As mentioned above, development of petroleum infrastructure and associated increase of human activity can have a negative effect on sage-grouse habitat quantity and quality. Currently the Alberta Fish and Wildlife Division employs a set of guidelines (http://www3.gov.ab.ca/srd/fw/landuse/) recommending timing and setback distances around sagegrouse leks in an attempt to ensure that potential essential habitat is not compromised. Once essential habitat is more clearly defined, refinements to habitat protection efforts will be incorporated into this system. 


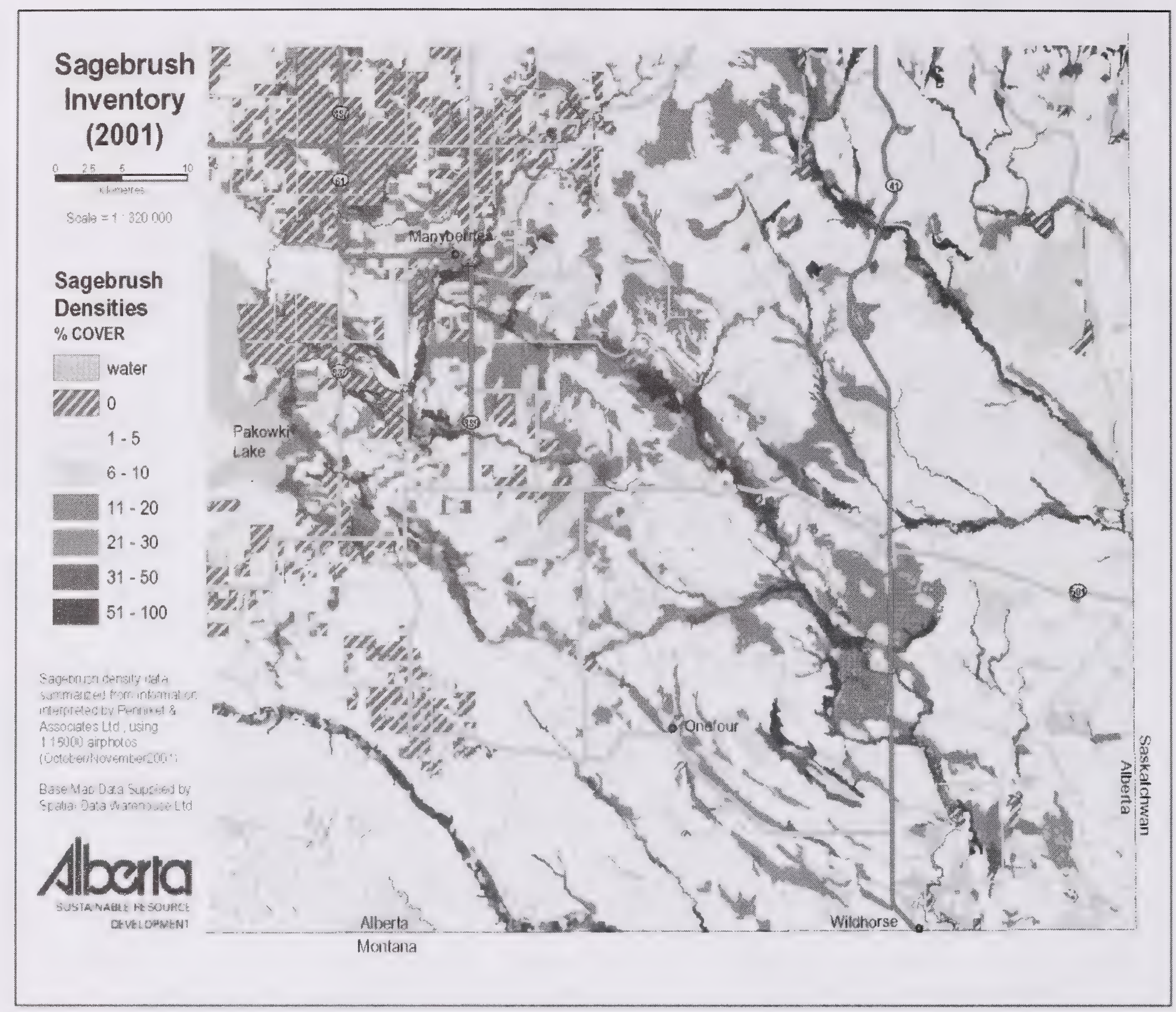

Figure 4: Sagebrush density in southeastern Alberta.

\subsection{INFORMATION GAPS AND RESEARCH PRIORITIES}

There is still a degree of uncertainty associated with topics related to sage-grouse ecology and habitat. These topics were identified in the Canadian Strategy as well as through meetings of the Technical Advisory Group. Members of the Technical Advisory Group were asked to rate the relative importance of each of these topics with respect to the deficiency of available information associated with the topic and the urgency of having the information for management. The result is that each identified research topic was scored on urgency for management and deficiency of information. In the chart below, the topics ranked highest for management urgency should take priority as action can be taken on these items as information becomes available. 


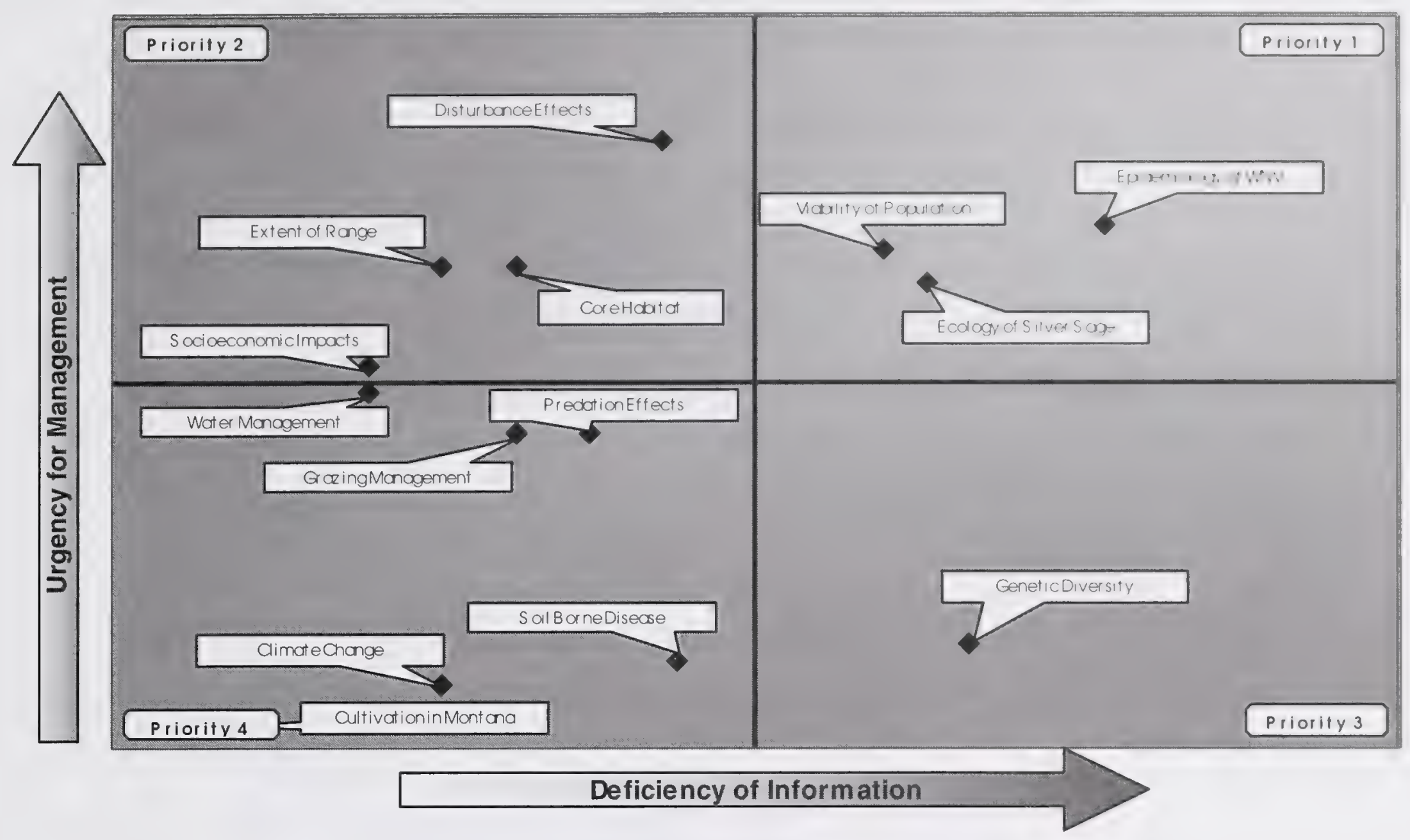

Figure 5. Results of research priority setting exercise.

Future research funding should be accordingly directed to areas of high management urgency and deficiency of information first, as important management decisions may be based on the outcome of the research. This exercise should be completed again when the recovery plan is under annual review as some research will be completed and other topics for research may be identified.

The results indicate that epidemiology of West Nile virus, ecology of silver sagebrush and the viability of the sage-grouse population are the most urgent priorities both in terms of lack of knowledge about these topics and their relative importance for taking management action. Second level of priority topics were rated high for management urgency, but lower for deficiency of information. In spite of lower assigned priority, these topics should be given fairly immediate attention given the level of uncertainty associated with them and the need for research to support management action. Other topics shown in boxes labeled Priority 3 and 4 could be addressed later as time and funds permit. During further discussion after the research priority setting exercise, it was also noted that research should be conducted on potential areas for reclamation.

\subsection{BIOLOGICAL AND TECHNICAL FEASIBILITY OF RECOVERY}

The sage-grouse population in Alberta is significantly reduced from historical levels, and may be vulnerable to factors such as disease, weather events and inbreeding. The biological viability of the population is currently not well understood, however population viability analysis for sagegrouse in Alberta is underway (Aldridge in prep.). Several of the listed threats can be managed 
to increase the amount of habitat available to grouse, thereby increasing the species chance for survival. For example, grazing can be used as a tool to enhance habitat rather than posing a threat to the species.

The current Alberta population of sage-grouse may be too small to facilitate a population increase that is necessary to support recovery of the species. For this reason, the translocation of sage-grouse to Alberta may be a critical component of recovery actions for this species. However, the SGRAG believes that recovery of sage-grouse is possible and will be facilitated by the following:

- There is remaining habitat to support sage-grouse at increased population levels.

- There is significant technical information (e.g., sage-grouse habitat use, grazing history of southeastern Alberta, sagebrush ecology) available from recent research projects to define management actions that will aid in recovery.

- There is interest in the local community to participate in sage-grouse recovery.

\subsection{RECOVERY STRATEGY}

\subsection{Recovery Goals}

Several of the listed threats are currently being managed in a manner that has positive effects on sage-grouse habitat. For example, Alberta Public Lands and Forests' policy to promote good range health was implemented to ensure long-term benefits for ranchers, yet it has benefits for sage-grouse as well (Adams et al. 2004). Thus, our recommendation is to continue with a focus on range health as a strategy for sage-grouse recovery and this is reflected in this recovery plan. However, further work must be done to enhance habitat and recovery beyond promoting existing policy.

The SGRAG was comprised of local potentially affected interests/sectors. The SGRAG developed 2 main goals for recovery based upon collaboration. The goals are as follows:

1. Enhance and maintain habitat for sage-grouse to satisfy life cycle requirements in support of a viable population within its remaining historical range.

2. Achieve recovery of the sage-grouse population to a level that provides for sustainable recreational viewing and hunting.

Actions under the goals will focus on habitat protection, conservation and reclamation; population enhancement and management; encouraging better stewardship of sage-grouse habitat by industry, landowners, lessees and recreational users; and outreach. When population goal is attained and the species is down listed, consideration will be given towards recreational viewing opportunities and re-establishing harvest through a carefully monitored hunting season. 
In order to achieve these goals, the following objectives and recovery actions are necessary. The objectives are measurable by the indicators outlined and accountability for measuring indicators, as well as completing recovery actions, has been assigned. The objectives are described in detail, along with associated indicators, methods for measuring and targets, in the Action Plan (Section 8). Under the Goal 1 (mentioned above) the objectives include:

- Protect known current and historical lek sites

- Enhancement of brooding, rearing and wintering habitat

- Manage for appropriate range health on both public and private lands

- Restore and enhance habitat quality through appropriate range management practices

- Review effectiveness of current guidelines for oil and gas development on native prairie in relation to sage-grouse and amend as necessary

- Disseminate information on the effects of industrial activities, grazing practices and recreational activities on sage-grouse

Goal 2 is supported by the following long-term objectives:

- Promote population recovery through development of a translocation program for sage-grouse from other jurisdictions

- Create recreational viewing opportunities

- Restore hunting opportunity

- Manage and mitigate impacts of resource development on sage-grouse habitat used during various life cycle stages

\subsection{Strategies for Achieving Recovery}

In order to achieve the goals of enhancing and maintaining sage-grouse habitat and recovery of sage-grouse populations, the Sage Grouse Recovery Action Group has recommended focusing on a number of strategies over the next five years. Grazing and oil and gas activity are key in sage-grouse habitat, and to that extent, it is important to concentrate on activities that will minimize impacts resulting from these industries. Finally, it is also important to ensure that best practices for sage-grouse management are communicated to those who make management decisions in the area. Thus, the strategies for reaching the goals include the following:

\section{Habitat Management, Conservation and Protection}

- Enhance and maintain a high standard of rangeland stewardship, providing for a sustainable ranching industry and high quality habitat for sage-grouse.

- Manage and mitigate the footprint of industry and foster good stewardship in energy planning and development in promotion of high quality sage-grouse habitat.

- Apply habitat protection measures (e.g., protective notations) where appropriate.

- Protocols for reclamation resulting from industrial disturbance in sage-grouse habitat need to be developed and applied as the opportunities and needs arise. 


\section{Population Management and Enhancement}

- Determine the feasibility of translocation for population augmentation as a management technique. The Western Agencies Sage- and Columbian Sharp-tailed Grouse Technical Committee under the Western Association of Fish and Wildlife Agencies is currently developing protocols for translocation as well as a priorization format. (Alberta is a cooperating member of WAFWA).

- Monitor population size, distribution and trends to: facilitate re-evaluation of the species' status; document prevalence of disease (WNV); and determine the effectiveness of recovery actions.

\section{Research}

- Research further exploring ecological relationships of sage-grouse with the landscape should be encouraged. This type of research is important so that management of this species and its habitat can be further refined. Current research efforts from the University of Alberta focused on Alberta sage-grouse include analysis of impacts of disease including West Nile Virus (J. Carpenter), genetics research (Krissy Bush) and Cam Aldridge's recently completed $\mathrm{PhD}$ dissertation on factors related to occurrence, survival, and viability of sage-grouse.

\section{Outreach and Information}

- Communicate information about sage-grouse management to land managers, industry, recreational users and other relevant parties in the area for the purpose of fostering stewardship of the species.

\section{Plan Management and Administration}

- All activities related to the operation of the Alberta Sage Grouse Recovery Action Group and implementation of the Alberta Sage Grouse Recovery Action Plan. A key element of this strategy is to build linkages with other provincial, national and international initiatives such as the Western Agencies Sage- and Columbian Sharp-tailed Grouse Technical Committee. 


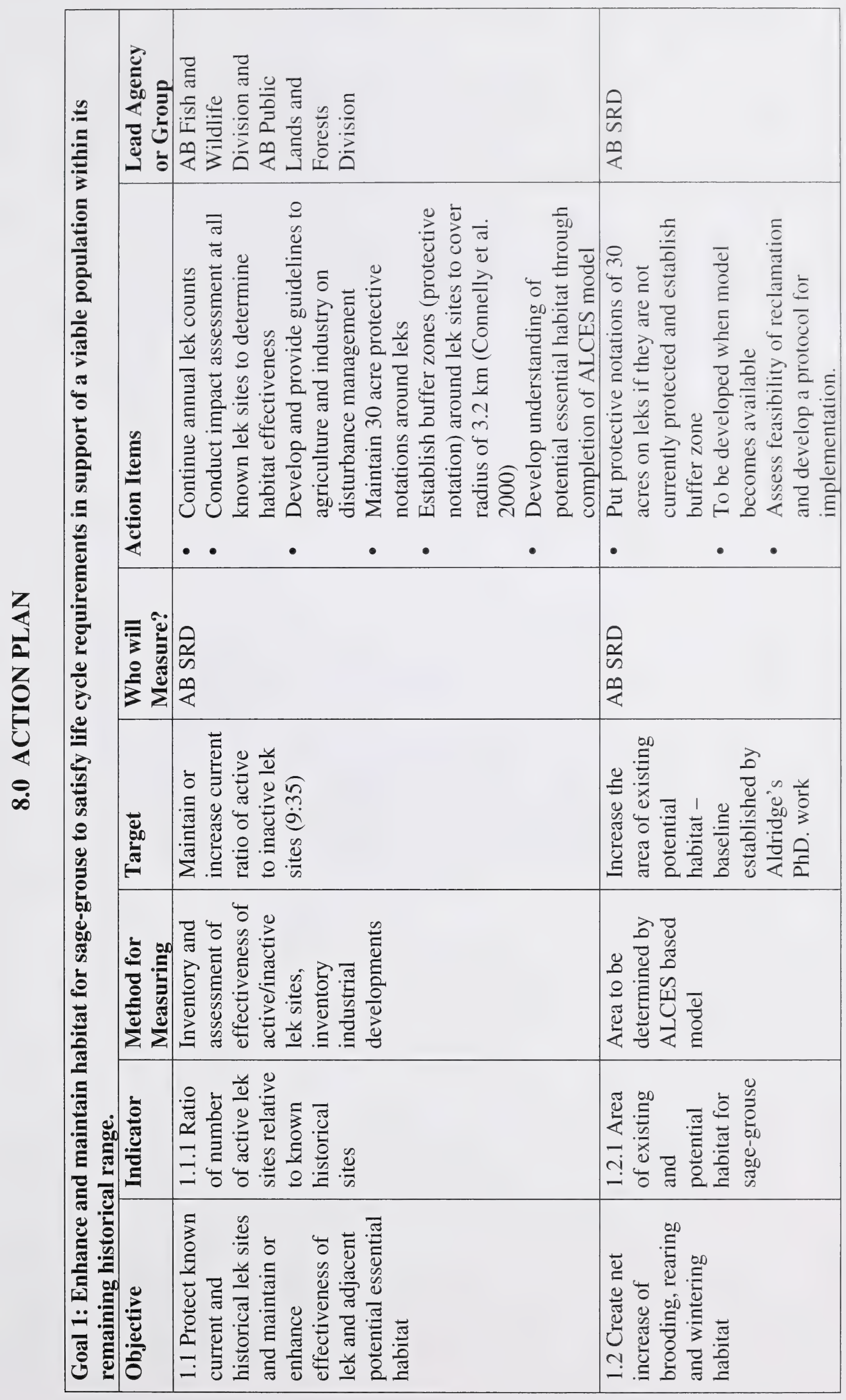




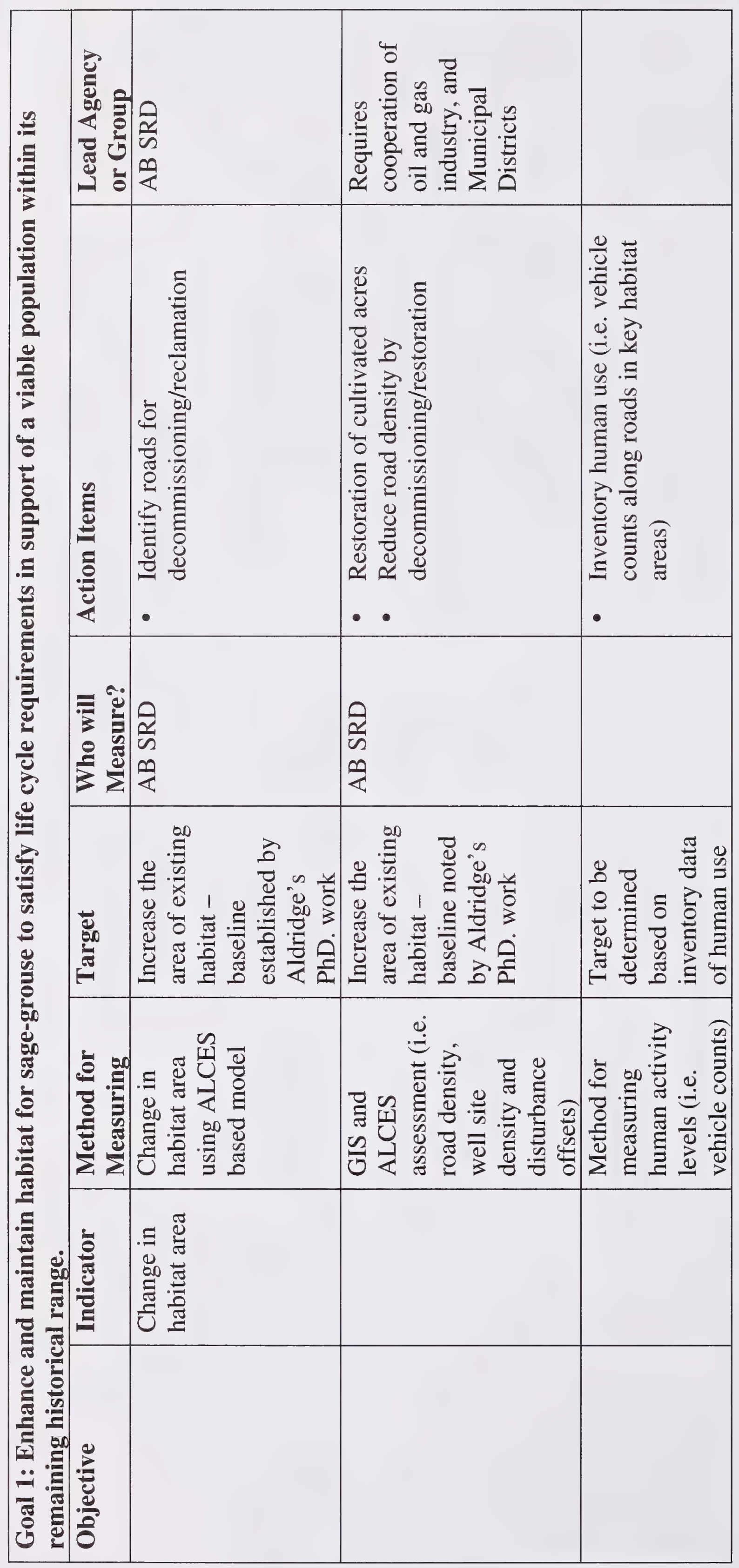




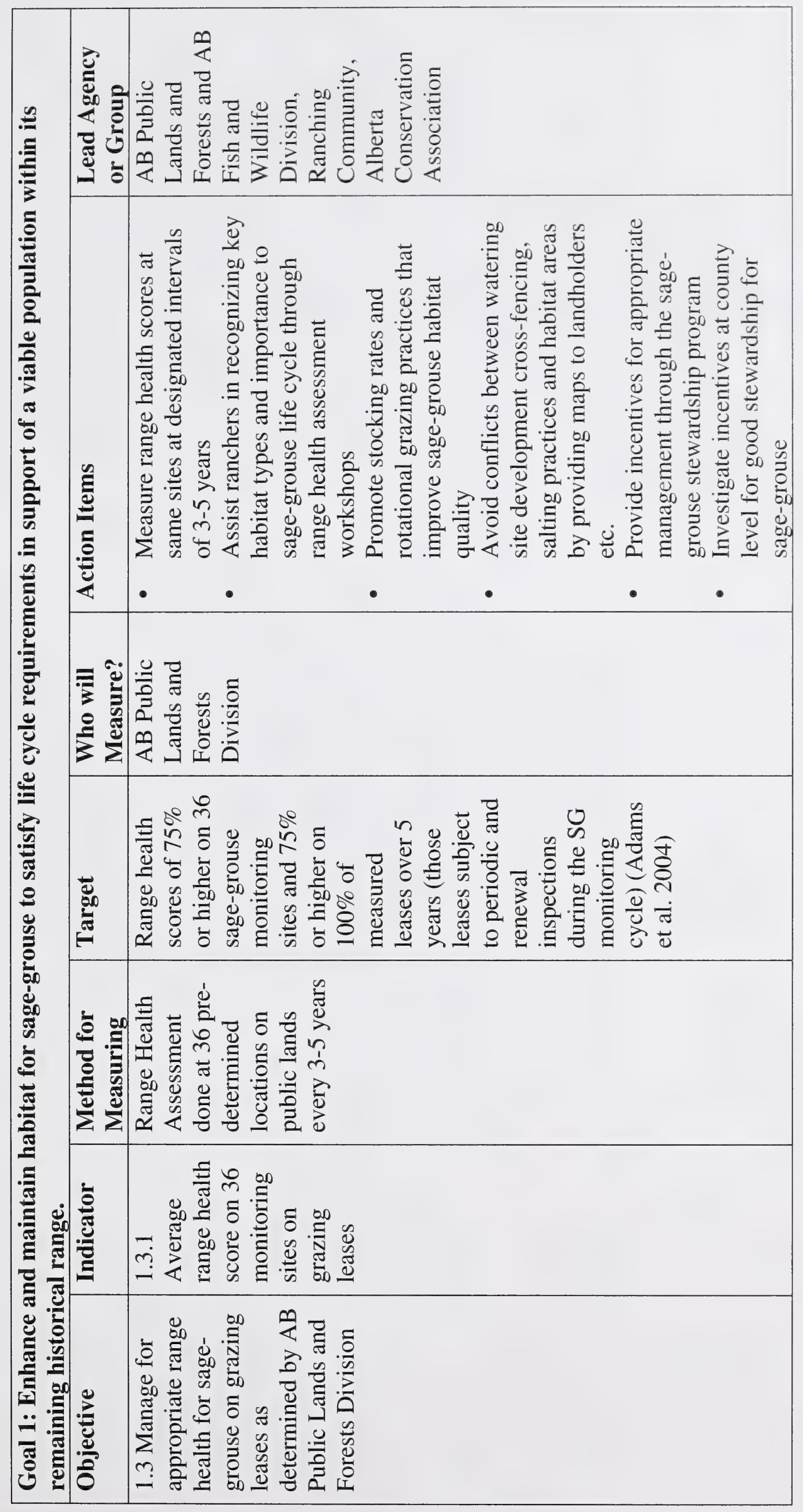




\begin{tabular}{|c|c|c|c|c|}
\hline . & 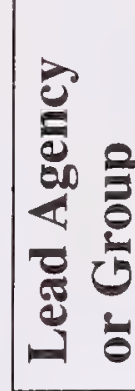 & & 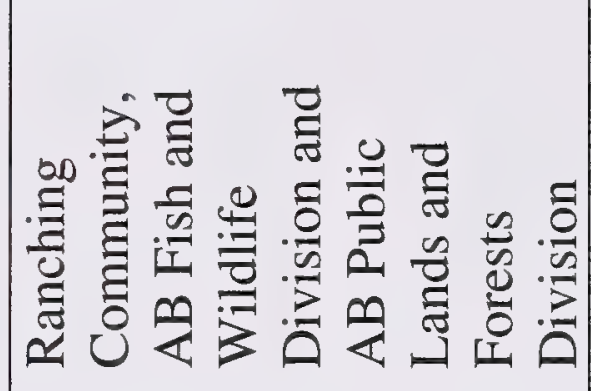 & 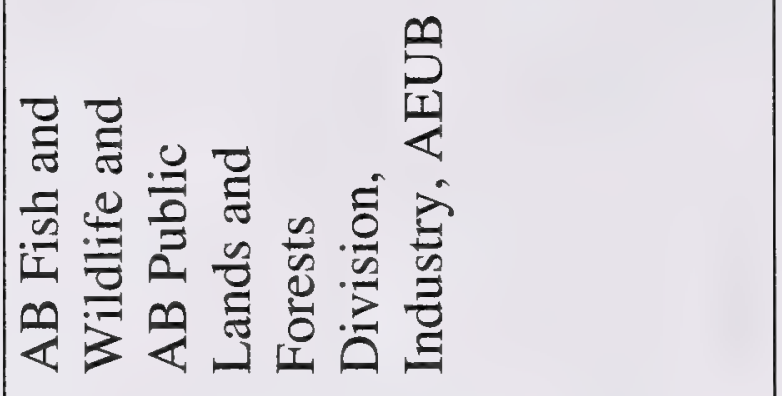 \\
\hline 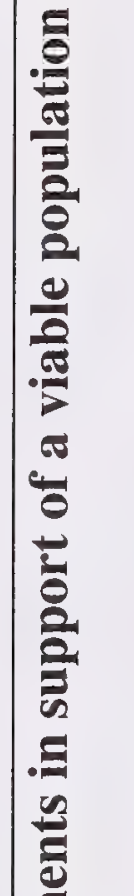 & 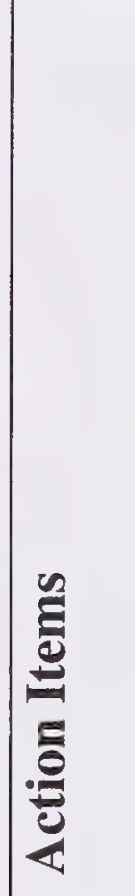 & 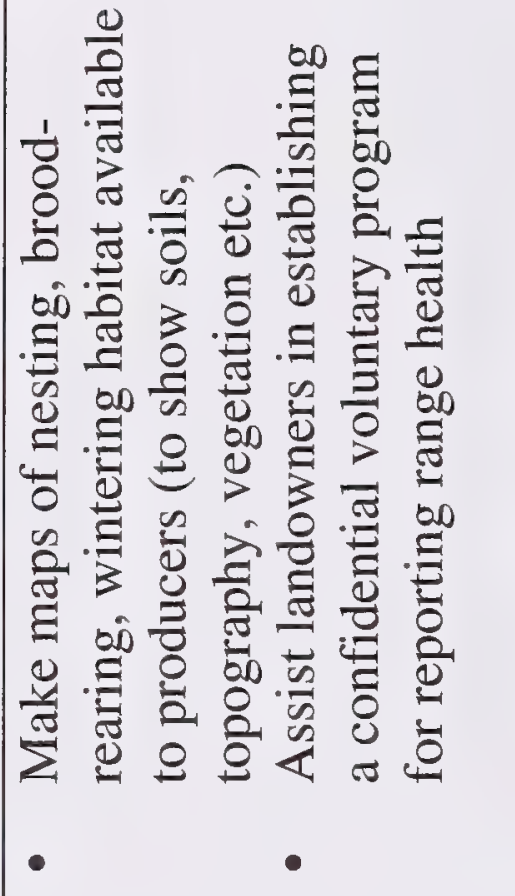 & 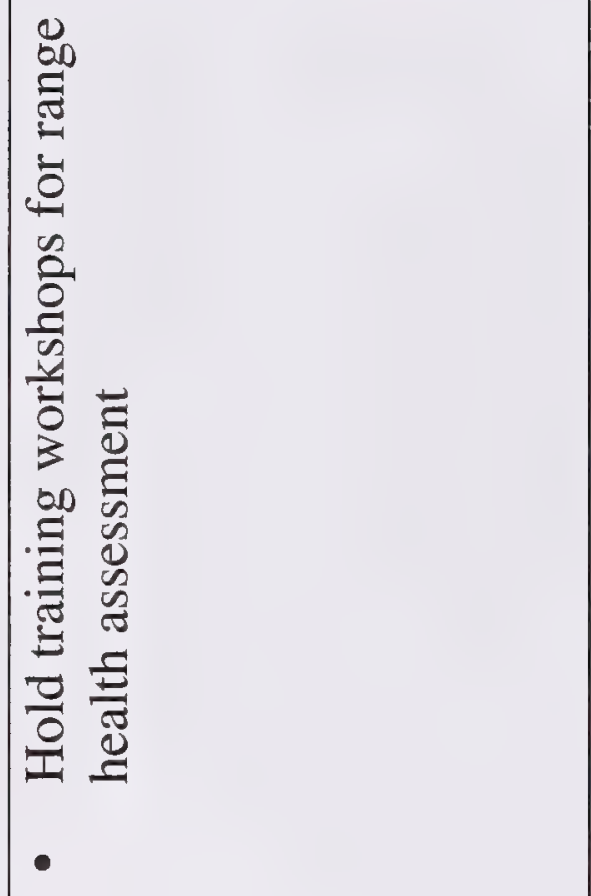 & 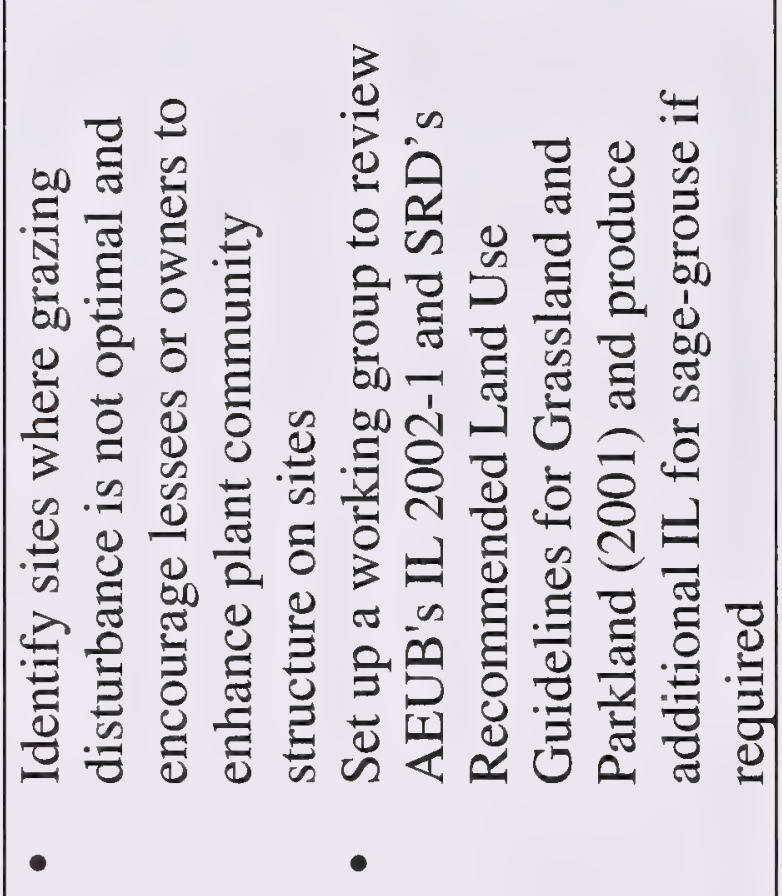 \\
\hline 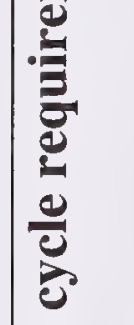 & 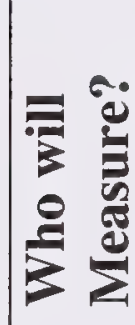 & 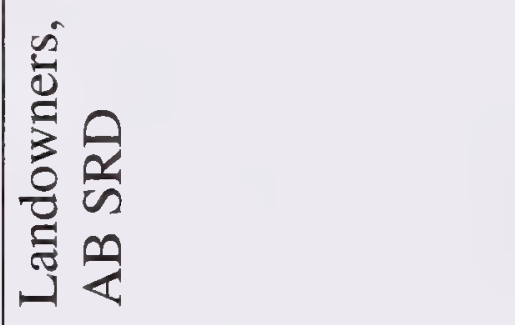 & 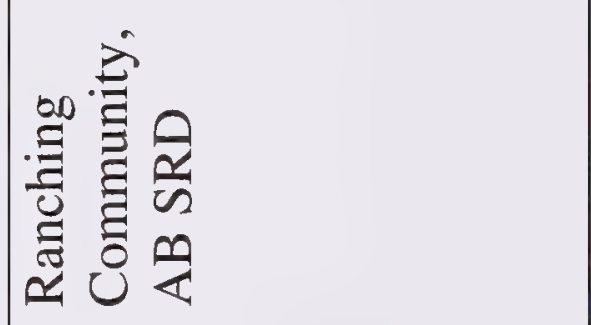 & 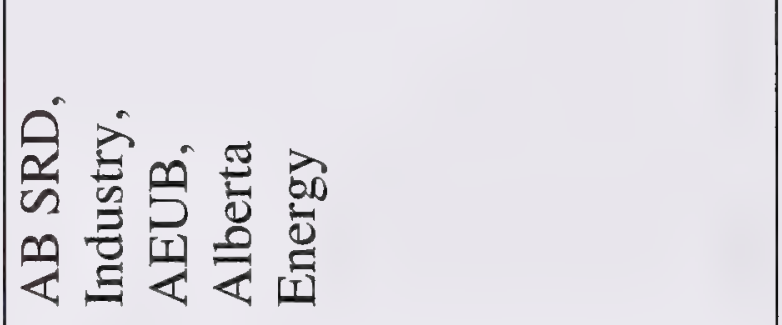 \\
\hline 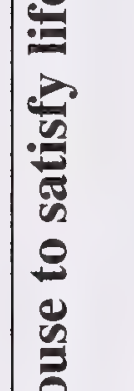 & 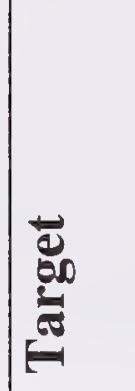 & 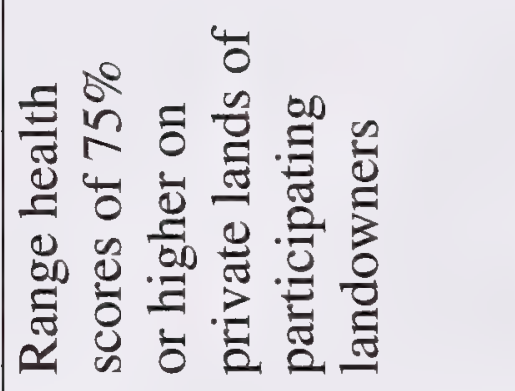 & 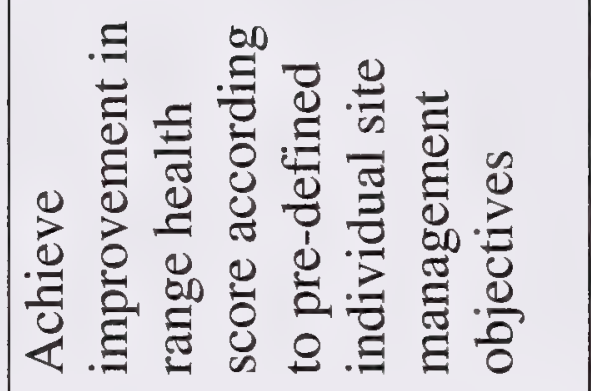 & 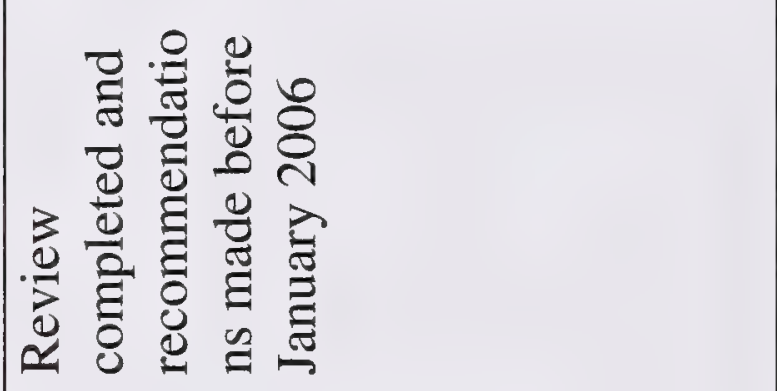 \\
\hline 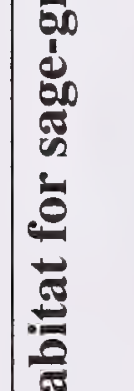 & 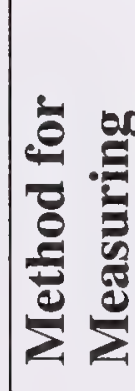 & 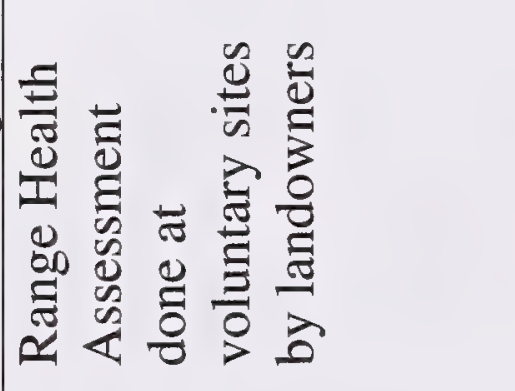 & 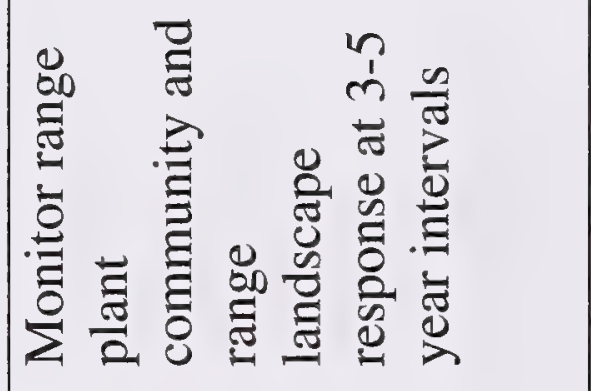 & 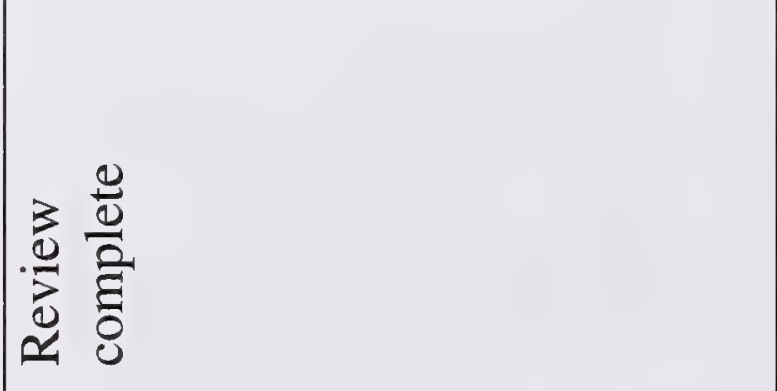 \\
\hline 㺼 & 节 & 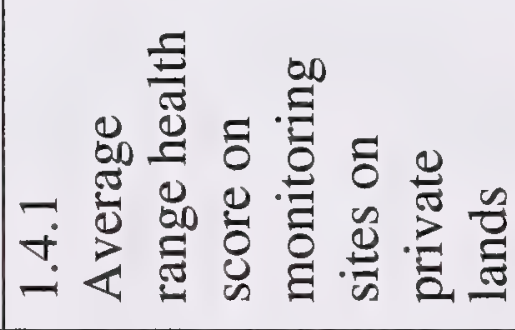 & 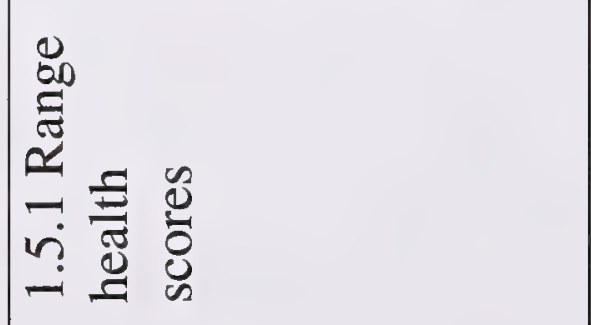 & - \\
\hline 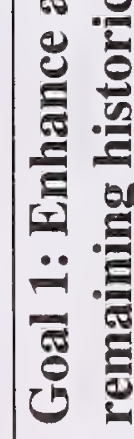 & $\frac{2}{0} \cdot \frac{2}{0}$ & 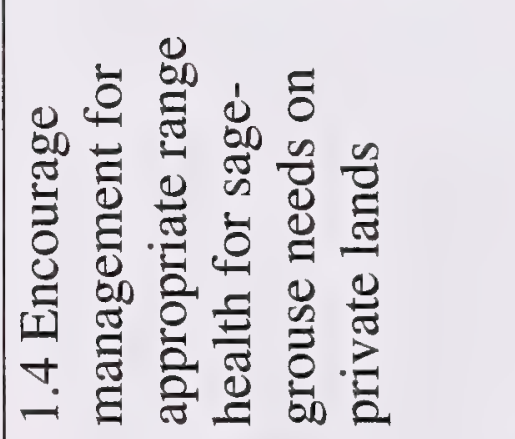 & 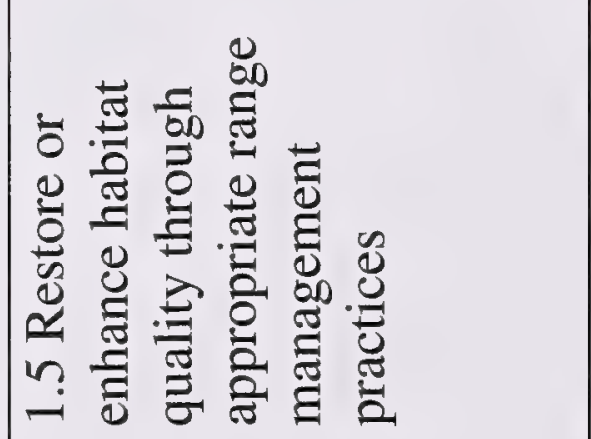 & 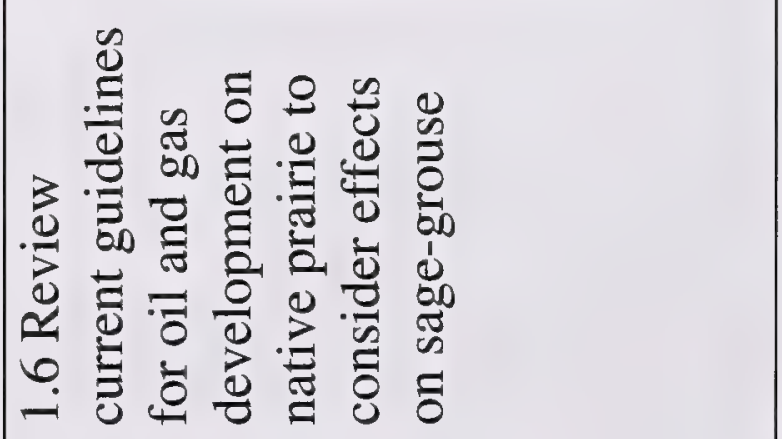 \\
\hline
\end{tabular}




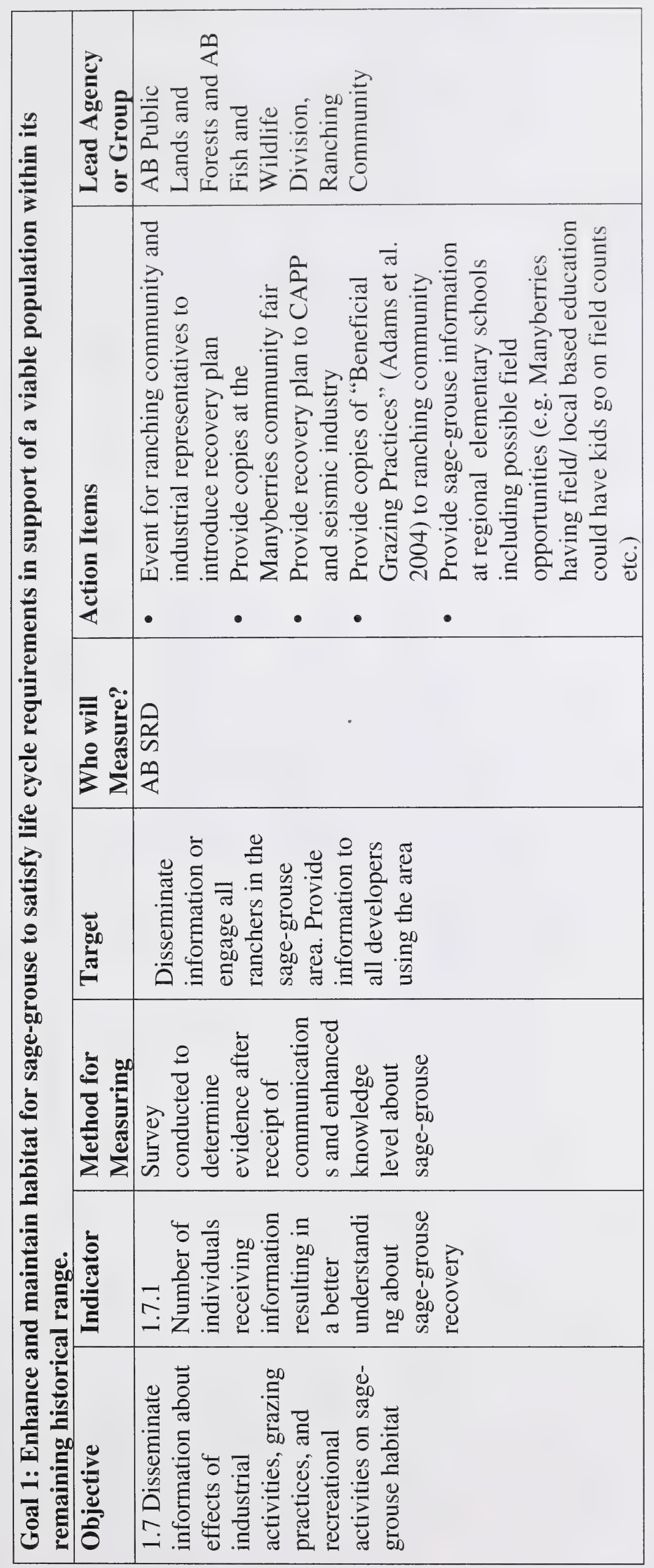




\begin{tabular}{|c|c|c|c|}
\hline & 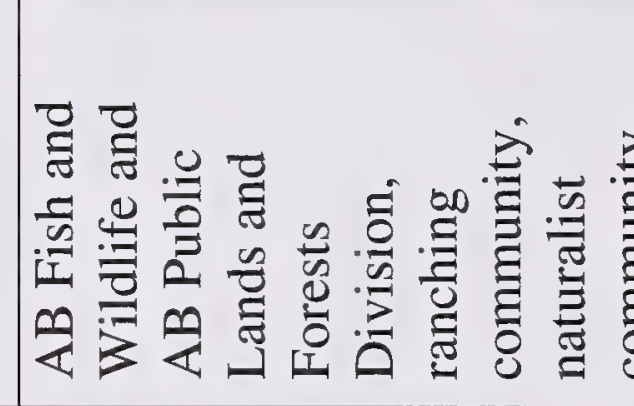 & 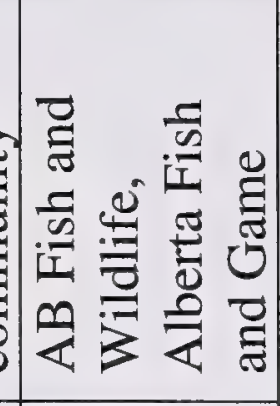 \\
\hline : & 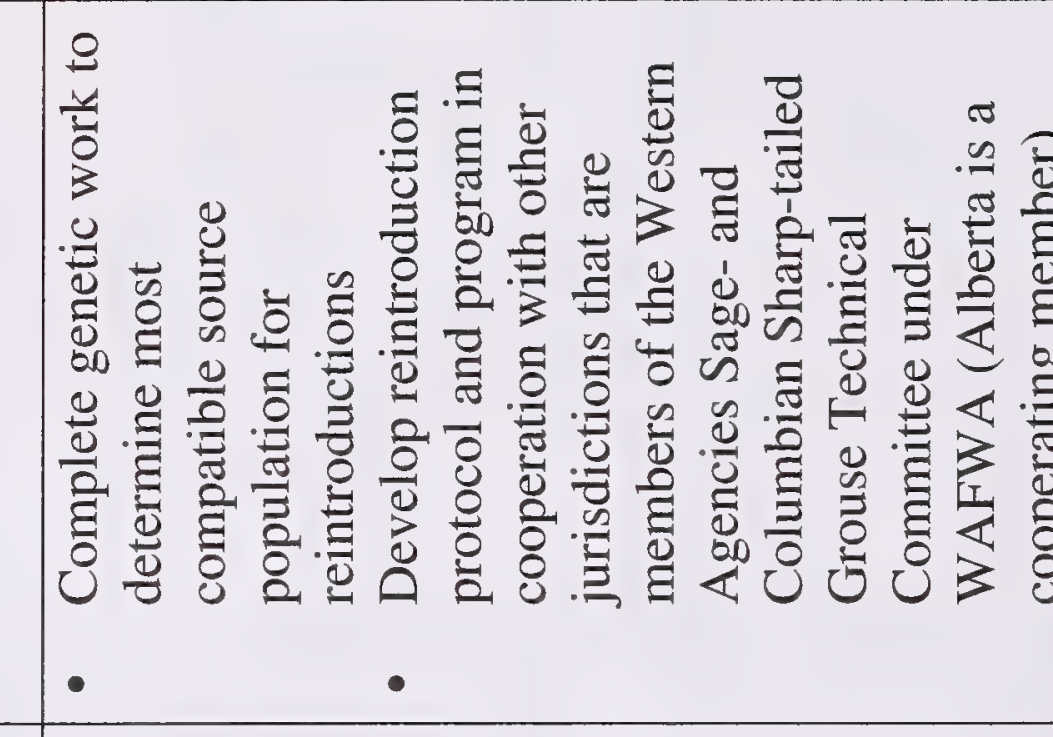 & 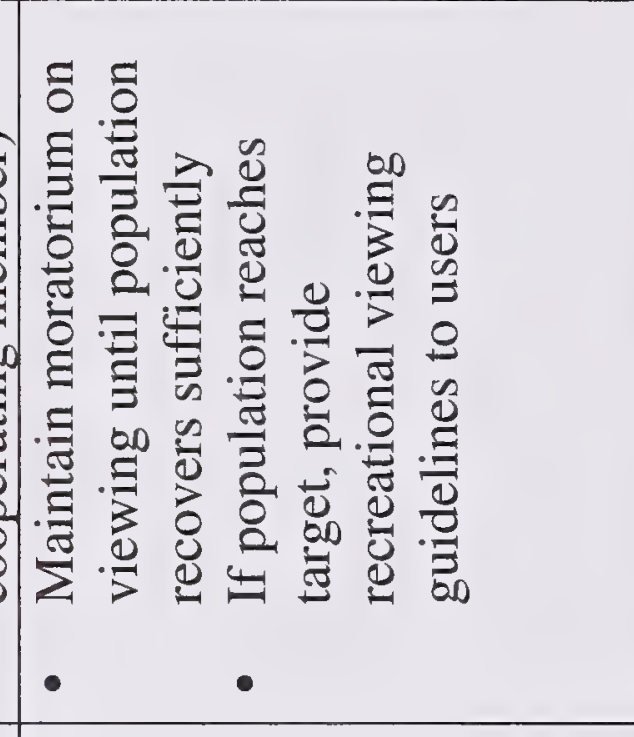 & 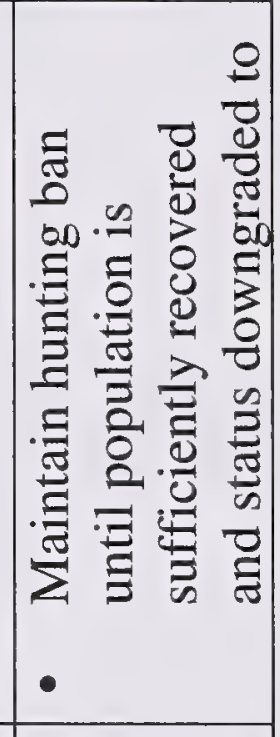 \\
\hline 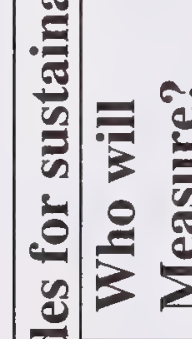 & 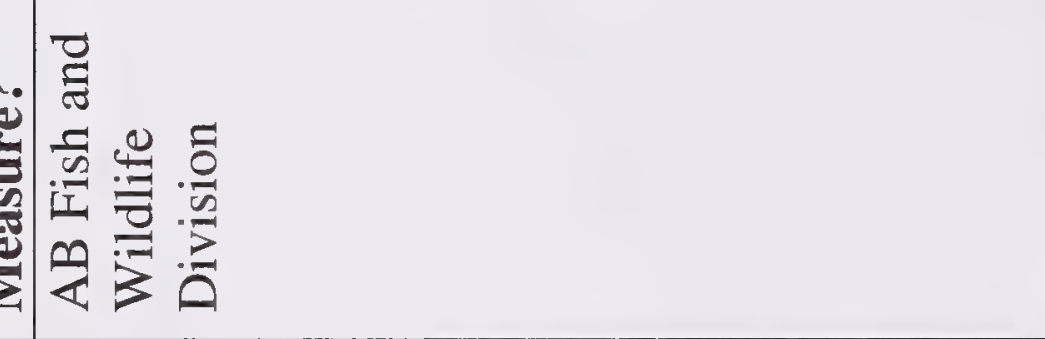 & 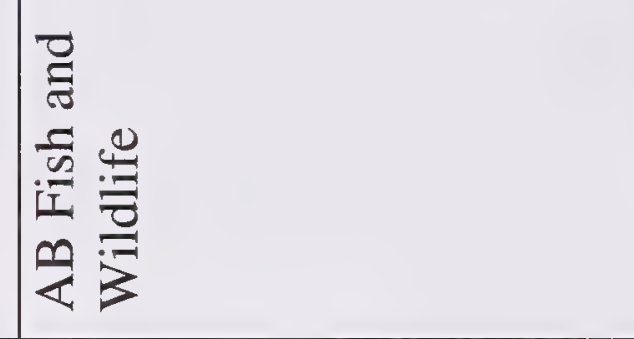 & 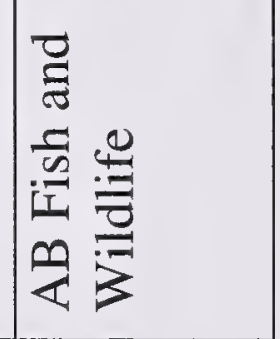 \\
\hline | & 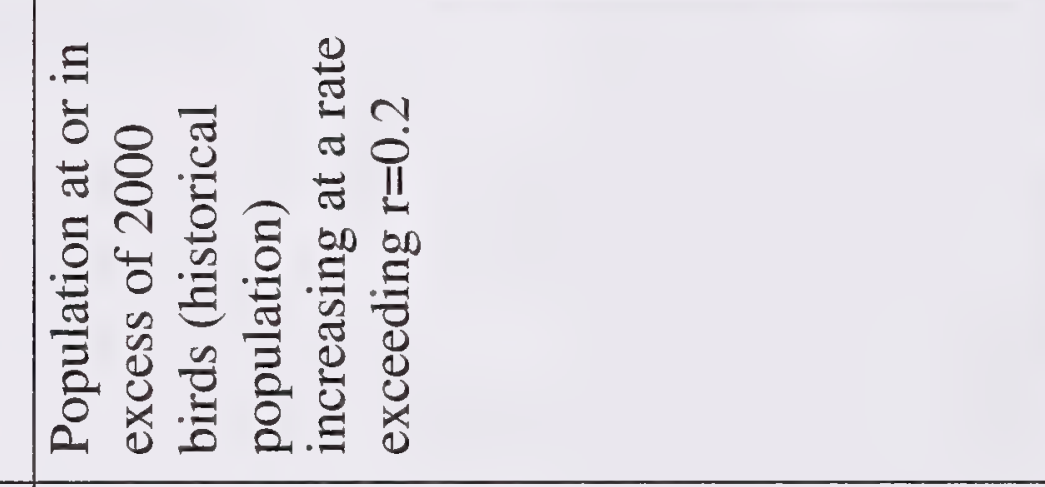 & 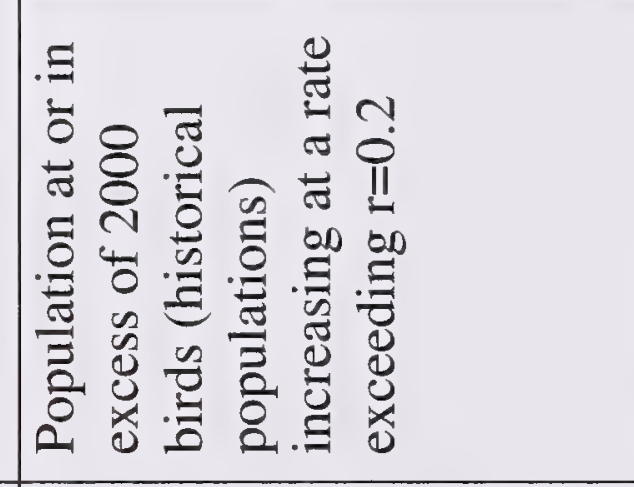 & 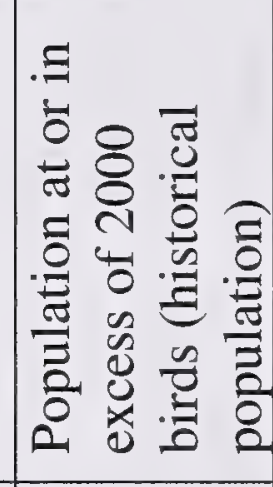 \\
\hline 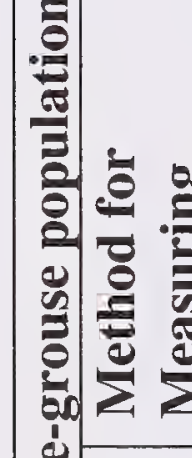 & 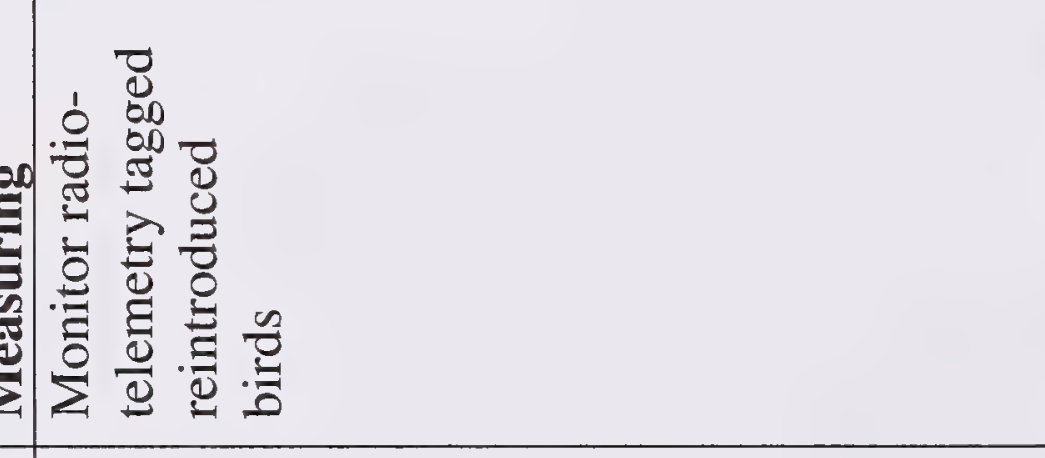 & 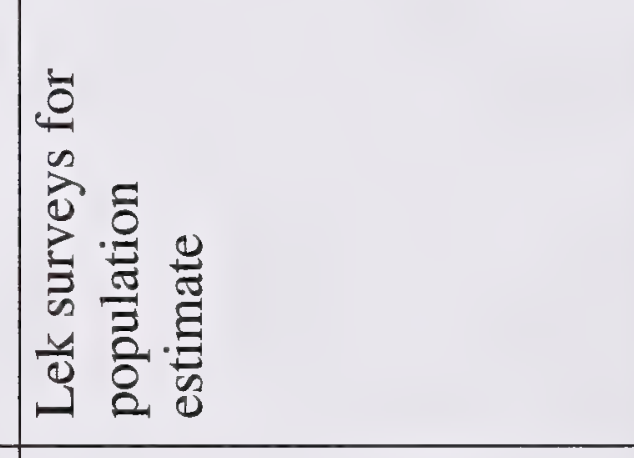 & 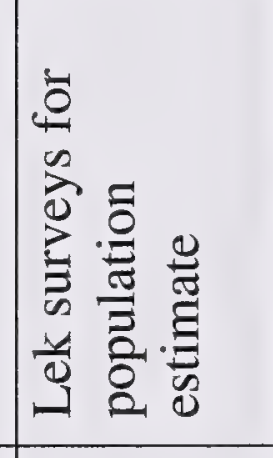 \\
\hline 吾 & 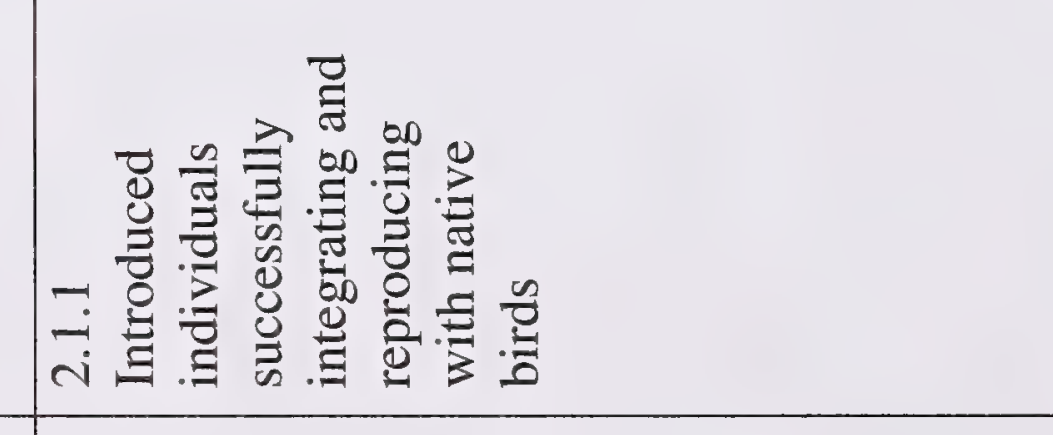 & 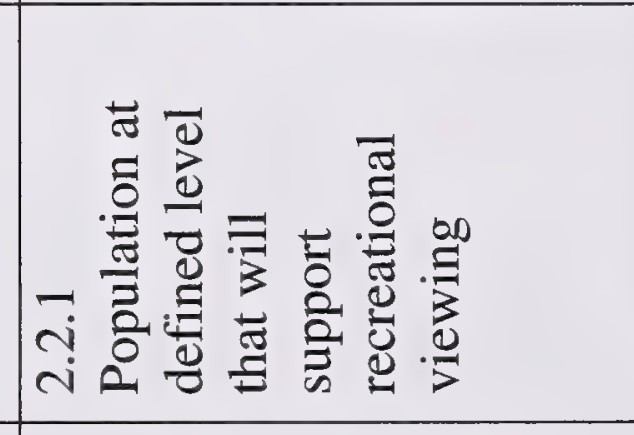 & 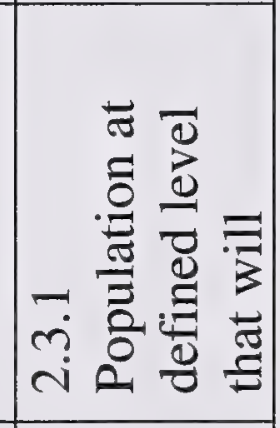 \\
\hline 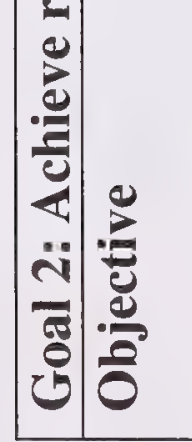 & 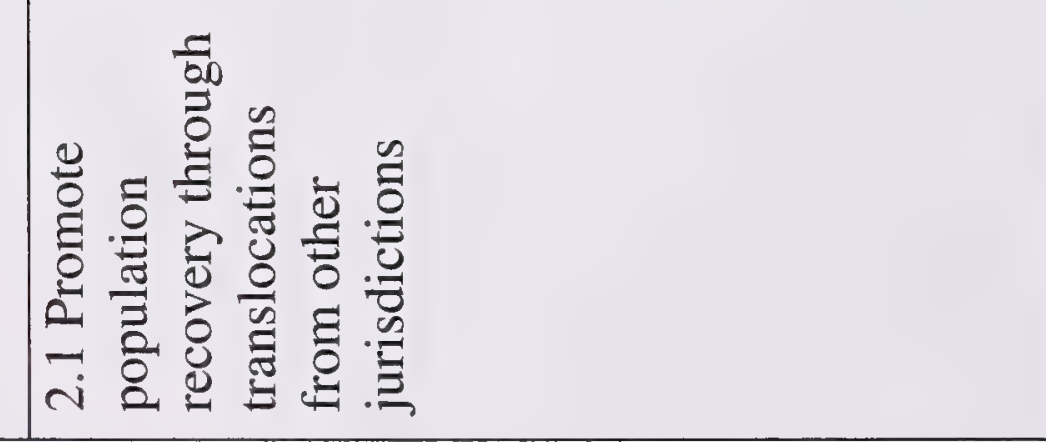 & 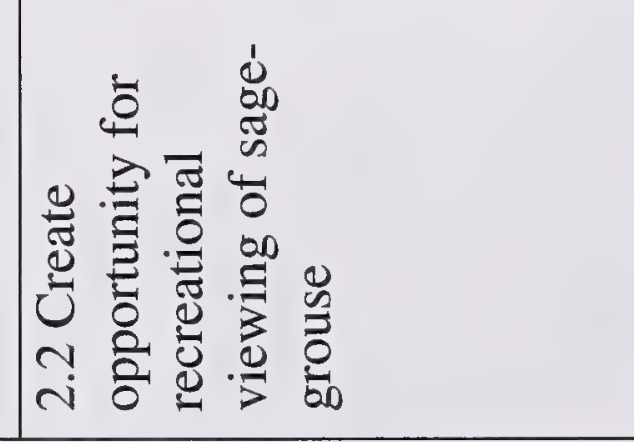 & 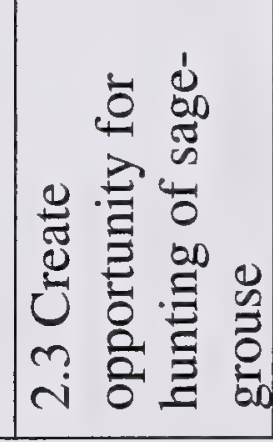 \\
\hline
\end{tabular}




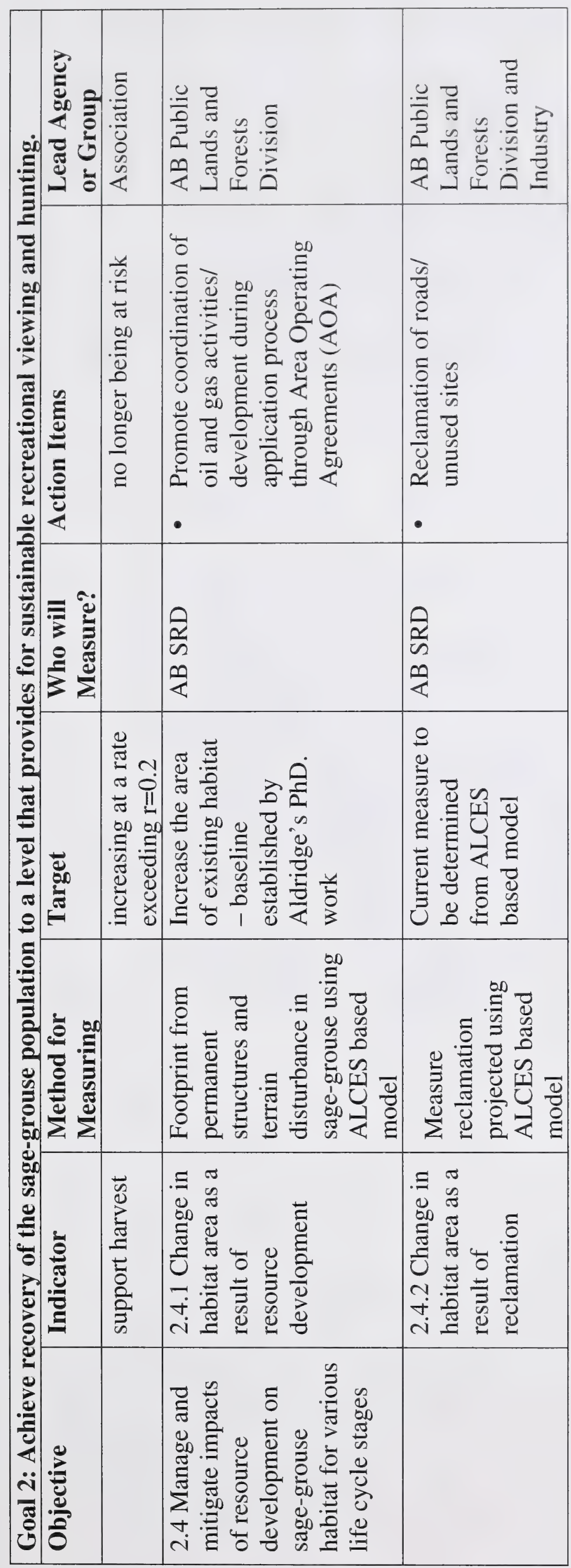




\subsection{TIMETABLE FOR IMPLEMENTATION AND SCHEDULE OF COSTS}

The following schedule provides a timeline for implementation of activities identified by the SGRAG as being important to the conservation of sage-grouse in Alberta, and provides an estimate of the costs (cash and in-kind) associated with their implementation. Based on available funds and budget restraints, it is anticipated that a variety of agencies will participate in the funding and implementation of these activities.

\begin{tabular}{|c|c|c|c|c|c|c|c|c|}
\hline \multirow[t]{2}{*}{ Objectiv } & \multirow[t]{2}{*}{ e|Activity } & \multirow[b]{2}{*}{ Agency } & \multicolumn{5}{|c|}{ Cost (thousands/year) } & \multirow[b]{2}{*}{ Total } \\
\hline & & & $\begin{array}{l}2005- \\
06\end{array}$ & $\begin{array}{l}2006- \\
07\end{array}$ & $\begin{array}{l}2007- \\
08\end{array}$ & $\begin{array}{l}2008- \\
09\end{array}$ & $\begin{array}{l}2009- \\
10\end{array}$ & \\
\hline \multirow[t]{8}{*}{1.1} & Continue annual lek counts & FWD & 5 & 5 & 5 & 5 & 5 & 25 \\
\hline & $\begin{array}{l}\text { Impact assessment of all } \\
\text { known lek sites to determine } \\
\text { habitat effectiveness }\end{array}$ & FWD, PLFD & 20 & 20 & 0 & 0 & 0 & 40 \\
\hline & \begin{tabular}{|l} 
Review and amend existing \\
guidelines guidelines to \\
agriculture and industry on \\
disturbance management
\end{tabular} & FWD, PLFD & 0 & 0 & 0 & 0 & 0 & 0 \\
\hline & $\begin{array}{l}\text { Maintain } 30 \text { acre protective } \\
\text { notations around leks }\end{array}$ & FWD, PLFD & 0 & 0 & 0 & 0 & 0 & 0 \\
\hline & $\begin{array}{l}\text { Map and describe buffer } \\
\text { zones around lek sites to } \\
\text { cover radius of } 3.2 \mathrm{~km} \\
\text { (Connelly et al. } 2000 \text { ) }\end{array}$ & FWD & 5 & 0 & 0 & 0 & 0 & 5 \\
\hline & $\begin{array}{l}\text { Put on consultative notations } \\
\text { within } 3.2 \mathrm{~km} \text { radius ensure } \\
\text { no conflicts with industrial or } \\
\text { other land use. }\end{array}$ & FWD & 5 & 0 & 0 & 0 & 0 & 5 \\
\hline & $\begin{array}{l}\text { Put protective notations of } 30 \\
\text { acres on leks if they are not } \\
\text { currently protected }\end{array}$ & FWD, PLFD & 5 & 0 & 0 & 0 & 0 & 5 \\
\hline & $\begin{array}{l}\text { Develop understanding of } \\
\text { potential essential habitat } \\
\text { through completion of } \\
\text { ALCES model }\end{array}$ & FWD, PLFD & 0 & 0 & 0 & 0 & 0 & 0 \\
\hline \multirow[t]{5}{*}{1.2} & $\begin{array}{l}\text { Increase habitat baseline as } \\
\text { per ALCES based model }\end{array}$ & FWD, PLFD & 10 & 10 & 0 & 0 & 0 & 20 \\
\hline & $\begin{array}{l}\text { Identify roads for } \\
\text { decommissioning/reclamation }\end{array}$ & AB SRD & 10 & 10 & 5 & 0 & 0 & 25 \\
\hline & \begin{tabular}{|l|} 
Assess feasibility of \\
reclamation and develop a \\
protocol for implementation
\end{tabular} & AB SRD & 0 & 0 & 0 & 0 & 0 & 0 \\
\hline & Cultivated acres restored & AB SRD & 50 & 50 & 50 & 50 & 50 & 250 \\
\hline & $\begin{array}{l}\text { Reduce road density by } \\
\text { decommissioning/restoration. }\end{array}$ & $\begin{array}{l}\text { AB SRD, } \\
\text { Industry }\end{array}$ & 50 & 50 & 50 & 50 & 50 & 250 \\
\hline
\end{tabular}




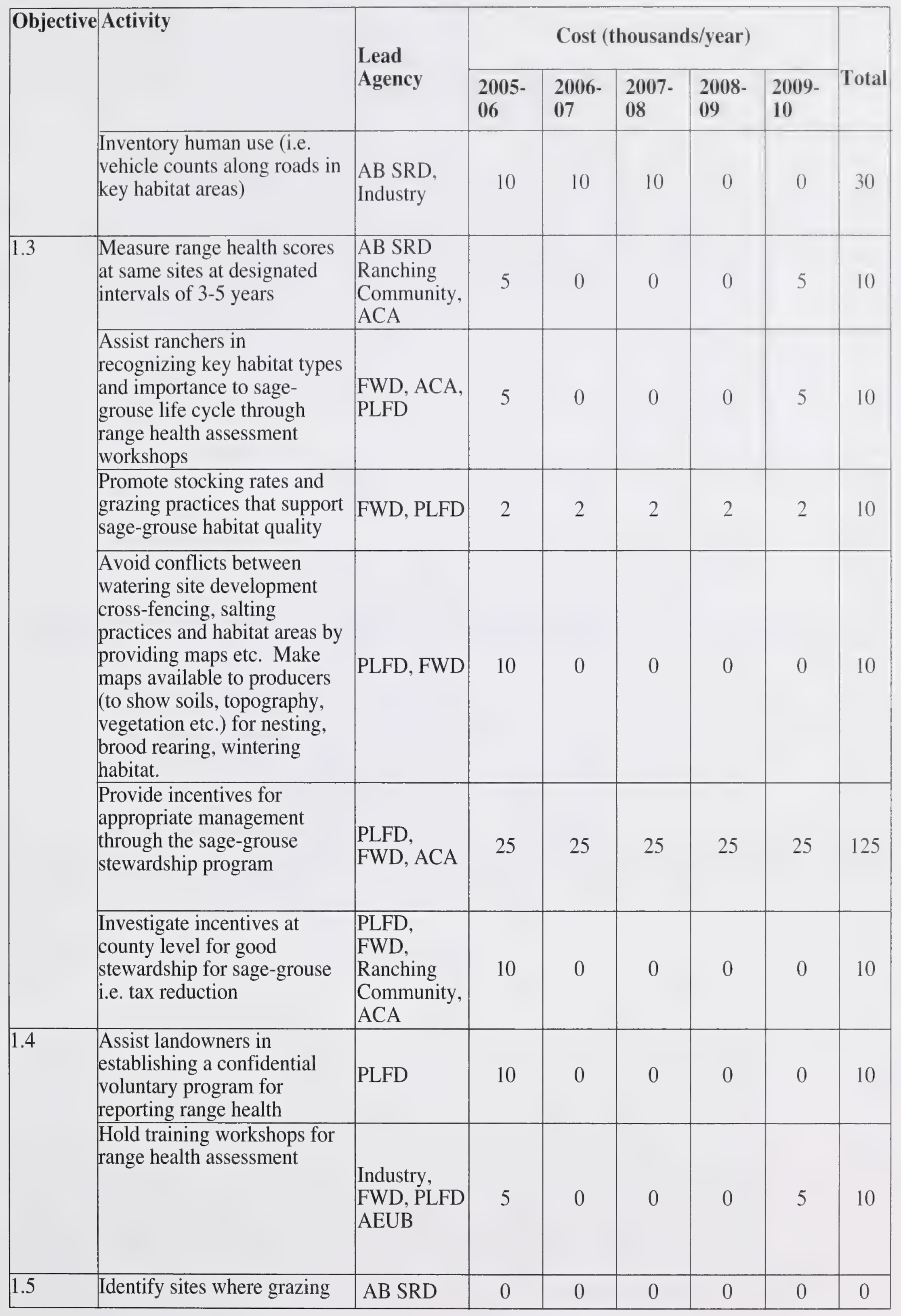




\begin{tabular}{|c|c|c|c|c|c|c|c|c|}
\hline \multirow[t]{2}{*}{ Objective } & \multirow[t]{2}{*}{ Activity } & \multirow{2}{*}{$\begin{array}{l}\text { Lead } \\
\text { Agency }\end{array}$} & \multicolumn{5}{|c|}{ Cost (thousands/year) } & \multirow[b]{2}{*}{ Total } \\
\hline & & & $\begin{array}{l}2005- \\
06\end{array}$ & $\begin{array}{l}2006- \\
07\end{array}$ & $\begin{array}{l}2007= \\
08\end{array}$ & $\begin{array}{l}2008 . \\
09\end{array}$ & $\begin{array}{l}2009 . \\
10\end{array}$ & \\
\hline & $\begin{array}{l}\text { disturbance is not optimal } \\
\text { and encourage lessees or } \\
\text { owners to enhance plant } \\
\text { community structure on sites }\end{array}$ & & & & & & & \\
\hline 1.6 & $\begin{array}{l}\text { Set up a working group to } \\
\text { review AEUB's IL 2002-1 and } \\
\text { SRD's Recommended Land } \\
\text { Use Guidelines for Grassland } \\
\text { and Parkland (2001) and } \\
\text { produce additional IL for } \\
\text { sage-grouse if required }\end{array}$ & FWD & 10 & 0 & 0 & 0 & 0 & 10 \\
\hline \multirow[t]{5}{*}{1.7} & $\begin{array}{l}\text { Event for ranching } \\
\text { community and industrial } \\
\text { representatives to introduce } \\
\text { recovery plan }\end{array}$ & FWD & 2 & 0 & 0 & 0 & 0 & 2 \\
\hline & $\begin{array}{l}\text { Provide copies at the } \\
\text { Manyberries community fair }\end{array}$ & FWD & 1 & 0 & 0 & 0 & 0 & 1 \\
\hline & $\begin{array}{l}\text { Provide recovery plan to } \\
\text { CAPP and seismic industry }\end{array}$ & FWD & 1 & 0 & 0 & 0 & 0 & 1 \\
\hline & $\begin{array}{l}\text { Provide copies of "Beneficial } \\
\text { Grazing Practices" (Adams et } \\
\text { al 2003) to ranching } \\
\text { community }\end{array}$ & $\begin{array}{l}\text { FWD, PLFD, } \\
\text { ACA }\end{array}$ & 1 & 1 & 1 & 0 & 0 & 3 \\
\hline & $\begin{array}{l}\text { Provide sage-grouse } \\
\text { information at regional } \\
\text { elementary schools including } \\
\text { possible field opportunities } \\
\text { (e.g. Manyberries having } \\
\text { field/ local based education } \\
\text { could have children } \\
\text { participate with field counts } \\
\text { etc.) }\end{array}$ & $\begin{array}{l}\text { PLFD, FWD, } \\
\text { Ranching } \\
\text { Community, } \\
\text { ACA }\end{array}$ & 2 & 2 & 2 & 2 & 2 & 10 \\
\hline \multirow[t]{2}{*}{2.1} & $\begin{array}{l}\text { Complete genetic work to } \\
\text { determine most compatible } \\
\text { source population for } \\
\text { reintroductions }\end{array}$ & $\begin{array}{l}\text { University of } \\
\text { Alberta }\end{array}$ & 6 & 0 & 0 & 0 & 0 & 6 \\
\hline & $\begin{array}{l}\text { Develop reintroduction } \\
\text { protocol and program in } \\
\text { cooperation with other } \\
\text { jurisdictions that are members } \\
\text { of the Western Agencies } \\
\text { Sage- and Columbian Sharp- } \\
\text { tailed Grouse Technical } \\
\text { Committee under WAFWA } \\
\text { (Alberta is a cooperating } \\
\text { member) }\end{array}$ & $\begin{array}{l} \\
\text { FWD, } \\
\text { Calgary } \\
\text { Zoological } \\
\text { Society }\end{array}$ & 20 & 100 & 100 & 50 & 50 & 320 \\
\hline
\end{tabular}




\begin{tabular}{|c|c|c|c|c|c|c|c|c|}
\hline \multirow[t]{2}{*}{ Objective } & \multirow[t]{2}{*}{ Activity } & \multirow{2}{*}{$\begin{array}{l}\text { Lead } \\
\text { Agency }\end{array}$} & \multicolumn{5}{|c|}{ Cost (thousands/year) } & \multirow[b]{2}{*}{ Total } \\
\hline & & & $\begin{array}{l}2005- \\
06\end{array}$ & $\begin{array}{l}2006- \\
07\end{array}$ & $\begin{array}{l}2007- \\
08\end{array}$ & $\begin{array}{l}2008- \\
09\end{array}$ & $\begin{array}{l}2009- \\
10\end{array}$ & \\
\hline \multirow[t]{2}{*}{2.2} & $\begin{array}{l}\text { Maintain moratorium on } \\
\text { viewing until population } \\
\text { recovers sufficiently }\end{array}$ & FWD & 0 & 0 & 0 & 0 & 0 & () \\
\hline & $\begin{array}{l}\text { If population reaches target, } \\
\text { provide recreational viewing } \\
\text { guidelines to users. }\end{array}$ & FWD & 0 & 0 & 0 & () & 2 & 2 \\
\hline 2.3 & $\begin{array}{l}\text { Maintain hunting ban until } \\
\text { population is sufficiently } \\
\text { recovered and status changed } \\
\text { to Special Concern. }\end{array}$ & FWD & 0 & 0 & 0 & 0 & 0 & 0 \\
\hline \multirow[t]{8}{*}{2.4} & $\begin{array}{l}\text { Promote coordination of oil } \\
\text { and gas activities/ } \\
\text { development during } \\
\text { application process through } \\
\text { Area Operating Agreements } \\
\text { (AOA) }\end{array}$ & PLFD, FWD & 0 & 0 & 0 & 0 & 0 & 0 \\
\hline & $\begin{array}{l}\text { Reclamation of roads/ unused } \\
\text { sites }\end{array}$ & $\begin{array}{l}\text { PLFD, } \\
\text { Industry }\end{array}$ & 0 & 0 & 0 & 0 & 0 & 0 \\
\hline & Plan Management & & & & & & & \\
\hline & $\begin{array}{l}\text { Annual Team } \\
\text { Meetings/Report }\end{array}$ & FWD & 1 & 1 & 1 & 1 & 1 & 5 \\
\hline & Database Management & FWD & 1 & 1 & 1 & 1 & 1 & 5 \\
\hline & Research Coordination & FWD & 0 & 0 & 0 & 0 & 0 & 0 \\
\hline & $\begin{array}{l}\text { Liaison with other Recovery } \\
\text { Teams active in sage-grouse } \\
\text { range }\end{array}$ & FWD & 0 & 0 & 0 & 0 & 0 & 0 \\
\hline & TOTAL & & 287 & 287 & 252 & 186 & 203 & 1215 \\
\hline
\end{tabular}

FWD - Alberta Fish and Wildlife Division; PLFD - Alberta Public Lands and Forests Division; ACA Alberta Conservation Association 


\subsection{ECONOMIC IMPLICATIONS OF RECOVERY ACTIONS}

The plan was developed through a collaborative process with all potentially affected local interests represented at the table. However, two key industries that operate in sagegrouse habitat have the potential to be impacted by the recovery actions. A brief assessment of the costs and benefits of this plan for ranching and the oil and gas industry are outlined.

\subsection{Activities Related to Ranching}

Actions associated with grazing are mainly focused on maintaining a range health score (RHS) at a minimum of $75 \%$. Monitoring is already being done on public lands in the area, and there will be some effort directed at promoting an RHS of $75 \%$ or better on private lands as well. Maintaining RHS at a minimum of $75 \%$ would be considered to be part of the normal grazing management objectives in the sage-grouse range and will be addressed through grazing lease agreements with Public Lands and Forests Division. Unsatisfactory grazing lease assessments require remedial management to achieve acceptable long-term range health levels. Prudent ranch management aims to manage for relatively stable stocking rates. This to a large extent is achieved through conservative stocking rates that maintain range health and a more stable forage supply. Potential economic stressors unrelated to the recovery plan could include increases in property taxes, and land values. Future incentives such as extended grazing lease tenure might be considered for providing improved levels of rangeland stewardship.

\section{$\underline{10.2 \text { Oil and Gas Industry }}$}

In this recovery plan, actions are aimed at minimizing the footprint of industrial activity within sage-grouse habitat. There are current guidelines in place, such as the AEUB Information Letter, 2000-1 Principles for Minimizing Surface Disturbance in Native Prairie and Parkland Areas and SRD's Recommended Land Use Guidelines for Grassland and Parkland (2001) that specify means to ensure minimal disturbance on native prairie. The SGRAG approves of using existing guidelines to mitigate effects on sage-grouse, therefore industry should not experience any immediate change in operational costs until the guidelines are modified or changed. Specific future changes to habitat guidelines may affect operational costs for industries. The guidelines are currently under SRD Fish and Wildlife Division regional review and changes could arise if more stringent measures result from reconsideration. 


\subsection{PLAN MANAGEMENT, REVIEW AND AMENDMENT}

Specific parts of this plan, namely measures and targets using the ALCES based models will be reviewed and updated one year after the approval of this plan. The ALCES based model is currently in development and should be available to the recovery team in the fall of 2005. Research underway at the University of Alberta will also provide a more complete picture of habitat selection by sage-grouse throughout life cycle stages and the effects of land use practices on sage-grouse, and should be available by the end of 2005 as well. The SGRAG will be asked to reconvene when further information becomes available. The recovery plan is to be reviewed annually and updated as required. Any updates will be forwarded to the Director of Wildlife Management for review and approval.

Specific management actions include meeting of SGRAG at a minimum of once annually, and circulate results of these meetings to interested persons. The plan should be monitored and assessed routinely so that new recovery strategies and actions can be developed when needed (adaptive management). Liaison with other provincial, national or international conservation agencies should occur to ensure continuity and flow of new information. Population data will be entered into the Biodiversity/Species Observation Database (BSOD) and other centralized databases following each field season. An annual report on recovery plan activities will be prepared and circulated.

In conclusion, it is recommended that this plan undergo major review and update at five year intervals to ensure that prescribed actions are contributing to the recovery goals set out. Given the five-year interval, this recovery plan should be subject to review in 2010. 


\subsection{REFERENCES}

(For a more extensive list of references relating to the background information contained within this document refer to the Canadian Sage Grouse Recovery Strategy, 2001)

Adams, B.W., J. Carlson, D. Milner, T. Hood, B. Cairns and Pat Herzog. 2004. Beneficial grazing management practices for Sage-Grouse (Centrocercus urophasianus) and ecology of silver sagebrush (Artemisia cana) in Southeastern Alberta. Technical Report, Public Lands and Forests Division, Alberta Sustainable Resource Development. Pub. No. T/049. 60 pp.

Alberta Energy Utilities Board. 2002. Informational Letter, IL 2002-1. Principles for Minimizing Surface Disturbance in Native Prairie and Parkland Areas.

Alberta Fish and Wildlife Division and Alberta Conservation Association. 2002. SageGrouse in Alberta: lifecycle, habitat requirements and conservation recommendations. Brochure prepared by Rangeland Conservation Service Ltd. Airdrie, AB.

Alberta Sustainable Resource Development (ASRD), Fish and Wildlife Division. 2001. Recommended land use guidelines for protection of selected wildlife species and habitat within Grassland and Parkland Natural Regions of Alberta. http://www3.gov.ab.ca/srd/fw/landuse/pdf/GrasslandParkland. (Last updated November 2001).

Alberta Wildlife Management Division. 1996. The Status of Alberta Wildlife. Alberta Environmental Protection, Natural Resource Service, Wildlife Management Division. Edmonton, AB. 42 pp.

Aldridge, C. L., and R. M. Brigham. 2002. Sage-grouse nesting and brood habitat use in southern Canada. Journal of Wildlife Management 66(2):433-444.

Aldridge, C.L., and R.M. Brigham. 2001. Nesting and reproductive activities of greater Sage-grouse in a declining northern fringe population. The Condor 103: 537-543.

Aldridge, C.L. 2000a. Reproduction and habitat use by Sage-Grouse (Centrocercus urophasianus) in a northern fringe population. Master's Thesis, University of Regina, Saskatchewan, Canada.

Aldridge, C.L. 2000b. Recommendations for the management of Sage-Grouse in Alberta. Unpublished document, Edmonton, AB.

Aldridge, C.L. 1998. Status of the Sage-Grouse (Centrocercus urophasianus urophasianus) in Alberta. Alberta Environmental Protection, Wildlife Management Division, and Alberta Conservation Association, Wildlife Status Report No. 13, Edmonton, AB. 23 pp. 
Anonymous. 1996. Working draft Gunnison sage-grouse Conservation Plan Gunnison Basin - Colorado. Last revised March, 1996. 52 pp.

Braun, C.E. 1998. Sage-grouse declines in western North America: what are the problems? Pp. 139-156. In: Baughman (Pres.). Proceedings of the Western Association of Fish and Wildlife Agencies, Jackson, Wyoming.

Braun, C.E., T. Britt, and R.O. Wallestad. 1977. Guidelines for maintenance of sagergrouse habitats. Wildlife Society Bulletin 5: 99-106.

Canadian Sage Grouse Recovery Team. 2001. Canadian Sage Grouse Recovery Strategy $55 \mathrm{pp}$.

Connelly, J. W., K. P. Reese, and M. A. Schroeder. 2003. Monitoring of greater sagegrouse habitats and populations. University of Idaho, College of Natural Resources Experiment Station Bulletin 80, Moscow. 50pp.

Connelly, J.W., M.A. Schroeder, A.R. Sands, and C.E. Braun. 2000. Guidelines to manage sage-grouse populations and their habitats. Wildlife Society Bulletin 28: 967-985.

COSEWIC. 2004. Canadian Species at Risk, May 2004. Committee on the Status of Endangered Wildlife in Canada. 49 pp.

Dube, L.A. 1993. Provincial sage grouse population trend counts, April - May, 1991.

Eustace, C.D. 1995. Sage grouse population status, its management and future for Western United States with emphasis on Montana. Fish, Wildl, and Parks Rept., Billings, Montana. and nest fate on timing of female sage grouse migration. Condor 98:868-872.

Forem Technologies Ltd. 2004. Alces Software. Box 805, Bragg Creek, AB, Canada TOL OK0

Gibson, R.M. 1996. Are-evaluation of hotspot settlement in lekking Sage-Grouse. Animal Behaviour 52: 993-1005.

Gilmer, D. S. and J. M. Wiehe. 1977. Nestling by ferruginous hawks and other raptors on high voltage powerline towers. Prairie Naturalist 9:1-10.

Gudmundson, L. 1996. Coyote population trends (1997-1996). Unpubl. Data., Environmental Protection, Natural Resources Service, Lethbridge, AB. 7pp.

Harris, W.C. 1996. Status of Saskatchewan sage grouse populations. Presented at 4th Prairie Conservation and Endangered Species Conference, February, 1995, Lethbridge, AB. 
Harris, W.C. and S. M. McAdam. 2000. Monitoring rare species in southwest Saskatchewan. Presented at Monitoring Ecosystem Health Conference, April 3-5, 2000, Regina, SK.

Hartzler, J.E., and D.A. Jenni. 1988. Mate choice by female sage-grouse. Pp. 240-269. In: A.T. Bergerud and M.W. Gratson (Eds.). Adaptive strategies and population ecology of northern grouse. University of Minnesota Press, Minneapolis.

Houston, C.S. 1999. Six declining grassland raptors: changes since the 1960s. Pages 2426 in Proc. 5th Prairie Conservation and Endangered Species Conference, Saskatoon, Saskatchewan, J. Thorpe, T.A. Steeves and M. Gollop, eds. Prov. Museum of Alberta Nat. Hist. Occas. Paper \#24, Edmonton, AB.

Jones, Paul F. Roy Penniket, Livio Fent, Joel Nicholson and Barry Adams. In press. Silver sagebrush Characteristics at the Landscape Level in South-eastern Alberta, Canada. Journal of Range Management. In Press.

Klausz, E.E. 1997. Small mammal winter abundance and distribution in the Canadian mixed grass prairie and implications for the swift fox. M.Sc. Thesis, Univ. Alberta, Edmonton, AB. 108 pp.

Knight, R. L. and J. Y. Kawashima. 1993. Responses of ravens and red-tailed hawk populations to linear right-of-ways. Journal of Wildlife Management 57:266-271.

McNeil, R.L. and B.J. Sawyer. 2003. Effects of Water Management Practices and Precipitation Events on Sagebrush Habitat in Southeastern Alberta. Prepared by Landwise Inc.,\#214-905-1 Ave. South, Suite 407, Lethbridge, AB., T1J 4M7 for Alberta Conservation Association and Alberta Sustainable Resource Development. Unpubl. rep. 36 pp.

Naugle, D.E., C.L. Aldridge, B.L. Walker, T.E. Cornish, B.J. Moynahan, M.J. Holloran, K.Brown, G.D. Johnson, E.T. Schmidtman, R.T. Mayer, C.Y. Kato, M.R. Matchett, T.J. Christiansen, W.E. Cook, T. Creekmore, R.D. Falise, E.T. Rinkes, and M.S. Boyce. 2004. West Nile virus: Pending crisis for Greater Sage-Grouse. Ecology Letters 7: 704-713.

Sadler, T. S. and M. T. Meyers. 1976. Alberta Birds 1961-1970. Occ. Paper No. 1 , Prov. Mus. of Alberta. Edmonton, AB. 314 pp.

Schroeder, M.A., J.R. Young, and C.E. Braun. 1999. Sage-Grouse (Centrocercus urophasianus). Pp. 1-26. In: A. Pool and F. Gill (Eds). The Birds of North America, No. 425. The Birds of North America, Inc., Philadelphia, PA.

Steenhof, K., M. N. Kochert and J. A. Roppe. 1993. Nesting by raptors and common ravens on electrical transmission line towers. Journal of Wildlife Management $57: 271-281$. 
Sveum, C.M., J.A. Crawford, W.D. Edge. 1998. Use and selection of brood rearing habitat by sage-grouse in south central Washington. Great Basin Naturalist 58 : 344-351.

The Canadian Sage Grouse Recovery Team. 2001. Canadian Sage Grouse Recovery Strategy. Unpublished report.

Watters, M.E., T.L. McLash, C.L. Aldridge, and R.M. Brigham. 2002. The effect of vegetation structure on the fate of artificial Greater Sage-Grouse nests. Ecoscience 9: 314-319. 
List of Titles in the Alberta Species at Risk Recovery Plan Series

(As of December 2005)

No. 1 Maintenance and Recovery Plan for Western Blue Flag (Iris missouriensis) in Canada. (2002)

No. 2 Alberta Piping Plover Recovery Plan 2002-2004. (2002)

No. 3 Alberta Peregrine Falcon Recovery Plan 2004-2010 (2005)

No. 4 Alberta Woodland Caribou Recovery Plan 2004/05 - 2013/14 (2005)

No. 5 Recovery plan for Ord's kangaroo rat in Alberta (2005)

No. 6 Recovery plan for burrowing owl in Alberta (2005)

No. 7 Alberta northern leopard frog recovery plan, 2005-2010 (2005)

No. 8 Alberta greater sage-grouse recovery plan (2005) 




$$
\text { • }
$$




LIBRARY AND ARCHIVES CANADA

|| Bibliothèque et Archives Canada

33286535327569 